Australian

National

University

Crawford School of Public Policy

\title{
CAMA
}

Centre for Applied Macroeconomic Analysis

\section{Debt and Financial Crises}

\section{CAMA Working Paper 9/2020 February 2020}

Wee Chian Koh

World Bank

M. Ayhan Kose

World Bank

Brookings Institution

Centre for Applied Macroeconomic Analysis, ANU

Peter S. Nagle

World Bank

Centre for Applied Macroeconomic Analysis, ANU

Franziska L. Ohnsorge

World Bank

Centre for Applied Macroeconomic Analysis, ANU

Naotaka Sugawara

World Bank 


\section{Abstract}

Emerging market and developing economies have experienced recurrent episodes of rapid debt accumulation over the past fifty years. This paper examines the consequences of debt accumulation using a three-pronged approach: an event study of debt accumulation episodes in 100 emerging market and developing economies since 1970; a series of econometric models examining the linkages between debt and the probability of financial crises; and a set of case studies of rapid debt buildup that ended in crises. The paper reports four main results. First, episodes of debt accumulation are common, with more than 500 episodes occurring since 1970. Second, around half of these episodes were associated with financial crises which typically had worse economic outcomes than those without crises- after 8 years output per capita was typically 6-10 percent lower and investment 15-22 percent weaker in crisis episodes. Third, a rapid buildup of debt, whether public or private, increased the likelihood of a financial crisis, as did a larger share of short-term external debt, higher debt service, and lower reserves cover. Fourth, countries that experienced financial crises frequently employed combinations of unsustainable fiscal, monetary and financial sector policies, and often suffered from structural and institutional weaknesses.

\section{Keywords}

Financial crises, currency crises, debt crises, banking crises, public debt, private debt, external debt

\section{JEL Classification}

E32, E61, G01, H12, H61, H63

\section{Address for correspondence:}

(E) cama.admin@anu.edu.au

ISSN 2206-0332

The Centre for Applied Macroeconomic Analysis in the Crawford School of Public Policy has been established to build strong links between professional macroeconomists. It provides a forum for quality macroeconomic research and discussion of policy issues between academia, government and the private sector.

The Crawford School of Public Policy is the Australian National University's public policy school, serving and influencing Australia, Asia and the Pacific through advanced policy research, graduate and executive education, and policy impact. 


\title{
Debt and Financial Crises
}

\author{
Wee Chian Koh, M. Ayhan Kose, Peter S. Nagle, \\ Franziska L. Ohnsorge, and Naotaka Sugawara*
}

This Version: January 2020

\begin{abstract}
Emerging market and developing economies have experienced recurrent episodes of rapid debt accumulation over the past fifty years. This paper examines the consequences of debt accumulation using a three-pronged approach: an event study of debt accumulation episodes in 100 emerging market and developing economies since 1970; a series of econometric models examining the linkages between debt and the probability of financial crises; and a set of case studies of rapid debt buildup that ended in crises. The paper reports four main results. First, episodes of debt accumulation are common, with more than 500 episodes occurring since 1970. Second, around half of these episodes were associated with financial crises which typically had worse economic outcomes than those without crises - after 8 years output per capita was typically 6-10 percent lower and investment 15-22 percent weaker in crisis episodes. Third, a rapid buildup of debt, whether public or private, increased the likelihood of a financial crisis, as did a larger share of short-term external debt, higher debt service, and lower reserves cover. Fourth, countries that experienced financial crises frequently employed combinations of unsustainable fiscal, monetary and financial sector policies, and often suffered from structural and institutional weaknesses.
\end{abstract}

Key Words: Financial crises, currency crises, debt crises, banking crises, public debt, private debt, external debt.

JEL Codes: E32, E61, G01, H12, H61, H63

\footnotetext{
* Wee Chian Koh (World Bank; wkoh@worldbank.org); M. Ayhan Kose (World Bank, Brookings Institution, CAMA; akose@worldbank.org); Peter Nagle (World Bank; pnagle@worldbank.org); Franziska Ohnsorge (World Bank, CAMA; fohnsorge@worldbank.org); and Naotaka Sugawara (World Bank; nsugawara@worldbank.org). We are grateful to Carlos Arteta, Justin-Damien Guénette, Jongrim Ha, Alain Kabundi, Sergiy Kasyanenko, Patrick Kirby, Franz Ulrich Ruch, Sandy Lei Ye, Dana Vorisek, and Shu Yu for their contributions to background research, literature reviews, and comments. We would like to thank Eduardo Borensztein, Kevin Clinton, Antonio Fatas, Erik Feyen, Catiana Garcia Kilroy, Ugo Panizza, Fernanda Ruiz-Nunes, Anderson Caputo Silva, Christopher Towe, and Igor Esteban Zuccardi, as well as participants at seminars and institutions around the world for many useful suggestions and comments. We thank Shijie Shi and Jinxin Wu for excellent research assistance. The findings, interpretations, and conclusions expressed in this paper are those of the authors. They do not necessarily represent the views of the institutions they are affiliated with.
} 


\section{Introduction}

Since the global financial crisis, global debt has reached an all-time high of roughly 230 percent of GDP in 2018. The increase has been driven by a synchronized buildup in debt among emerging market and developing economies (EMDEs), with total (public and private) debt in these countries reaching a record-high of almost 170 percent of GDP in 2018, an increase of 54 percentage points of GDP since 2010. The rapid increase (almost 80 percent of EMDEs have seen an increase in their debt-to-GDP ratio since 2010) has led to a lively debate about the benefits and risks of such rapid debt accumulation (Kose et al. 2020).

Borrowing can be beneficial for countries, particularly in EMDEs with substantial development challenges, if it is used to finance growth-enhancing investments in areas such as infrastructure, health care, and education. Government debt accumulation can also be appropriate temporarily as part of counter-cyclical fiscal policy, to boost demand and activity in economic downturns. For the private sector, borrowing can facilitate consumption smoothing among households, and investment for corporations.

However, particularly for EMDEs, high debt carries significant risks, since it makes them more vulnerable to external shocks. Rising or elevated debt increases a country's vulnerability to economic and financial shocks-including increases in the costs of refinancing - which can culminate in financial crises, with large and lasting adverse effects on economic activity. Such episodes of rapid debt accumulation followed by financial crises have been a recurrent feature among EMDEs over the past fifty years.

As such, despite exceptionally low real interest rates, including at long maturities, the current post-crisis surge in debt could follow the historical pattern and eventually lead to financial crises in EMDEs. A sudden global shock, such as a sharp rise in interest rates or a spike in risk premia, could trigger financial stress in more vulnerable economies.

Against this backdrop, this paper provides a granular perspective on the consequences of debt accumulation by addressing the following questions: First, what are the main features of episodes of rapid debt accumulation? Second, what are the empirical links between debt accumulation and financial crises? Third, what are the major institutional and structural weaknesses associated with financial crises?

To shed light on these questions, this paper uses a three-pronged approach: an event study; a series of econometric models; and an examination of episodes of crises via comprehensive country case-studies. The paper reports four main findings:

Debt accumulation episodes. Since 1970, there have been about 520 episodes of rapid debt accumulation in 100 EMDEs. Such episodes are therefore common: In the average year, three-quarters of EMDEs were in either a government or a private debt accumulation episode or both.

Debt and financial crises. About half of the debt accumulation episodes were accompanied by financial crises. Debt accumulation episodes that coincided with crises were typically associated with larger debt buildups (for government debt), weaker economic outcomes, and larger macroeconomic and financial vulnerabilities than non-crisis episodes. After 8 
years, GDP and GDP per capita were around 6-10 percent lower in crisis episodes, while investment was 15-22 percent lower. Crises in rapid government debt buildups featured significantly larger output losses than crises in rapid private debt buildups, while outcomes were particularly weak when crises coincided with combined government and private debt accumulation episodes.

Likelihood of financial crises. A rise in debt, either government or private, was associated with a higher probability of crisis in the following year. In addition, a combined accumulation of both government and private debt resulted in a higher likelihood of a currency crisis than solely-government or solely-private debt increases. Financial crises were typically triggered by external shocks such as sudden increases in global interest rates, but domestic vulnerabilities often amplified the adverse impact of these shocks. Crises were more likely, or the economic distress they caused was more severe, in countries with higher external debt - especially short-term - and lower international reserves.

Crises associated with inadequate policy frameworks. Most EMDEs that experienced financial crises during debt accumulation episodes employed various combinations of unsustainable macroeconomic policies, such as poor revenue collection, monetary financing of fiscal deficits, and use of subsidies. They also frequently suffered structural and institutional weaknesses, including inadequate regulatory regimes, and suffered from poor debt management. Several EMDEs that experienced crises also suffered from protracted political uncertainty.

This paper makes several novel contributions to the already extensive literature on the linkages between debt and financial crises. First, it undertakes the first comprehensive empirical study of the many episodes of government and private debt accumulation since 1970 in a large number of EMDEs. It considers not only what happened during the financial crises associated with rapid debt accumulation, but also examines macroeconomic and financial developments during the episodes of debt accumulation. Earlier work has often examined developments in government or private debt markets separately, analyzed these developments over short time intervals around financial crises, or focused on a narrow group of (mostly advanced) economies or regions. ${ }^{1}$

Second, the paper expands on earlier empirical studies of the correlates of crises by analyzing the linkages between debt accumulation and the probability of financial crises in a single empirical framework and by extending the horizon of analysis to the period 1970-2018. Earlier studies have examined government debt crises (Manasse, Roubini, and Schimmelpfenning 2003), private debt crises (Borio and Lowe 2002; Demirgüç-Kunt and Detragiache 1998; Kaminsky and Reinhart 1999) or both (Dawood, Horsewood, and Strobel 2017; Frankel and Rose 1996; Rose and Spiegel 2012). However, while some earlier studies examined the roles of different types of debt and a host of potential correlates of crises, they typically examined the linkages between a composite indicator of

\footnotetext{
${ }^{1}$ For example, government debt crises have been discussed in Abbas, Pienkowski, and Rogoff (2019); Kindleberger and Aliber (2011); Reinhart, Reinhart, and Rogoff (2012); Reinhart and Rogoff (2011); and World Bank (2019a). Credit booms have been examined in Dell'Arricia et al. (2014, 2016); Elekdag and Wu (2013); Jordà, Schularick, and Taylor (2011); Mendoza and Terrones (2008, 2012); Ohnsorge and Yu (2016); Schularick and Taylor (2012); and Tornell and Westermann (2005).
} 
vulnerabilities and crises. In contrast, the empirical approach here zooms in on the linkages between debt and financial crises.

Third, the paper presents a comprehensive review of country case studies of rapid debt accumulation episodes associated with financial crises. Based on a literature review that extracts common themes from a large set of country case studies, this complementary qualitative approach helps identify the major structural and institutional weaknesses associated with financial crises.

The rest of the paper is organized as follows. First, it examines the features of episodes of rapid private and government debt accumulation in an event study framework. Next, it outlines an empirical methodology to analyze how debt accumulation affects the likelihood of financial crises, controlling for other factors. This is followed by a review of selected country case studies to identify the major macroeconomic, structural and institutional weaknesses in national debt accumulation episodes that were associated with financial crises. The paper concludes with a summary of findings.

\section{National debt accumulation episodes}

This section reviews the main features of rapid debt accumulation episodes-periods where the increase in public or private debt has been particularly rapid - and their linkages with financial crises in an event study.

\subsection{Methodology}

Identification of episodes. The identification of episodes of rapid accumulation of government and private debt proceeds in two steps. First, a statistical algorithm (following Harding and Pagan (2002)) is used to identify the cyclical turning points in the debt-to-GDP ratios. In particular, a debt cycle (from one peak debt-to-GDP ratio to the next peak debt-to-GDP ratio) is assumed to last at least five years with a minimum twoyear duration of the contraction phase (from peak to trough) and the expansion (or accumulation) phase (from trough to peak). Second, an expansion phase is labeled as a rapid accumulation episode if an increase in the debt-to-GDP ratio (from trough to peak) exceeds the maximum of ten-year moving standard deviations (over the period t-9 to t) of the debt-to-GDP ratio during the phase (Figure 1). Episodes at the beginning and end of the data series are similarly classified, but the beginning and end of episodes are set at the points where the availability for government and private debt data begins and ends.

Application of this algorithm results in 256 episodes of rapid government debt accumulation and 263 episodes of rapid private debt accumulation in a sample of 100 EMDEs with available data for $1970-2018 .^{2}$ This identification algorithm for rapid debt accumulation episodes closely follows methods used to date the turning points of business cycles (Claessens, Kose, and Terrones (2012); Harding and Pagan (2002); and Mendoza and Terrones (2012)). The headline results are robust to using a definition more closely aligned with the literature on credit booms.

\footnotetext{
${ }^{2}$ Small states, as defined by the World Bank, are excluded.

45 government debt and 38 private debt accumulation episodes are still ongoing. Appendixes 1 and 2 list government and private debt accumulation episodes.
} 
In scaling debt by GDP, this approach implicitly focuses on the concept of the debt burden, which captures the ability of borrowers economy-wide to service their debt. In principle, a sharp increase in the debt burden, as measured by the debt-to-GDP ratio, could mechanically reflect: an output collapse; deflation; an exchange rate depreciation that raises the domestic currency value of debt; or a large increase in borrowing. Regardless of the underlying cause, a rise in the debt burden makes it more challenging for the economy to service debt and makes the debt burden more likely to become a source of financial stress.

In practice, output contractions were a source of increased debt-to-GDP ratios in a minority of the rapid debt accumulation episodes identified here (one-third of government debt episodes and two-fifths of private debt episodes). Sharp currency depreciations (in currency crises) have been associated with larger debt buildups during debt accumulation episodes, but such depreciations have typically happened before (usually two years before) debt peaks. The increase in debt during the year of the currency crisis has accounted for only between one-tenth (private debt episodes) and one-quarter (government debt episodes) of the total debt buildup during episodes involving currency crises.

Episodes associated with financial crises. Financial crises (banking, sovereign debt, or currency crises) are defined as in Laeven and Valencia (2018). Data for currency crises are extended to 2018 using the same methodology as Laeven and Valencia (2018). ${ }^{3}$ A rapid debt accumulation episode is identified as having been associated with a financial crisis (of any type) if such a crisis occurred at any point between the start of the episode and the year of the episode's peak debt-to-GDP ratio or within two years of the peak debt-to-GDP ratio. Appendix 3 lists financial crises in EMDEs. Some debt accumulation episodes were associated with multiple financial crises. For example, Mexico's government debt accumulation episode of 1980-87 spanned a banking crisis in 1981, and currency and debt crises in 1982. Turkey's government debt accumulation episode of 1998-2001 spanned a banking crisis in 2000 and a currency crisis in 2001 .

This identification approach describes an association between rapid debt accumulation and financial crises without necessarily implying any causal link between the two. This approach yields 137 rapid government debt accumulation episodes associated with crises and 105 rapid private debt accumulation episodes associated with crises between 1970 and 2018 in 100 EMDEs.

\subsection{Main features of episodes}

Frequency of episodes. Debt accumulation episodes have been common (Figure 2). In the average year between 1970 and 2018, three quarters of EMDEs were in either a government or a private debt accumulation episode or both. The region with the most episodes was Sub-Saharan Africa (where 34 percent of all government and 33 percent of all private debt accumulation episodes occurred), in part reflecting the large number of countries in the region but also its history of debt dependence. The average EMDE in Sub-Saharan Africa (SSA), South Asia (SAR), and Latin American and the Caribbean (LAC) - the regions with the most episodes per country - went through three government

\footnotetext{
${ }^{3}$ Other studies dating crises include, for example, Baldacci et al. (2011); Reinhart and Rogoff (2009); and Romer and Romer (2017).
} 
and three private debt accumulation episodes between 1970 and 2018. Central African Republic, Niger, and Togo had the most (five) government debt accumulation episodes, including ongoing ones. Argentina, Burkina Faso, Myanmar, Oman, Pakistan, United Arab Emirates, and Zambia had the most (also five) private debt accumulation episodes. Several countries had only one debt accumulation episode (either private or government) in the period (for example, Albania, Cote d'Ivoire, and Serbia).

Duration. The duration of episodes - the number of years from trough to peak debt-toGDP ratios - varied widely but amounted to about 7 and 8 years in the median government and private debt accumulation episode, respectively (Table 1). Most accumulation episodes were short-lived. The shortest episode lasted two years in, for example, Benin (1992-94; government debt), Lao PDR (1996-98; government debt), and Papua New Guinea (1996-98; private debt).

Most episodes had run their course in less than a decade. However, 21 percent of government debt episodes and 29 percent of private debt episodes lasted for more than a decade. The long duration of some of these episodes suggests that the debt buildup in part reflected healthy financial deepening. This may be especially the case in those countries with exceptionally long accumulation episodes.

Amplitude. Although again with wide heterogeneity among the episodes, the debt buildup in the median episode amounted to 21 percentage points of GDP. The government debt buildup in the median government debt accumulation episode (30 percentage points of GDP from trough to peak) was double the private debt buildup in the median private debt accumulation episode (15 percentage points of GDP from trough to peak). The largest increases in government debt-to-GDP ratios took place in lower-income countries in SSA and LAC over several decades; the largest increases in private debt-to-GDP ratios occurred in ECA, and the smallest in SSA.

Variation in the amplitude of debt accumulation episodes across countries was particularly wide for government debt accumulation episodes. In one-quarter of such episodes, the government debt buildup typically amounted to more than 50 percentage points of GDP. For example, government debt rose by 127 percentage points of GDP in Argentina (19922002) and 86 percentage points of GDP in Mozambique (2007-16). Debt accumulation of such a scale was rare for the private sector: in three-quarters of private debt accumulation episodes, private debt rose by less than 30 percentage points of GDP. There were some exceptions: private debt rose by 86 percentage points of GDP in Hungary (1995-2009), 76 percentage points of GDP in Turkey (2003-2018), and 89 percentage points of GDP in China (2008-18).

Combined episodes. About 70 percent of government and private debt accumulation episodes overlapped. These overlapping, combined government and private episodes, were statistically significantly shorter and often more pronounced in amplitude than solelyprivate or solely-government debt accumulation episodes (Table 2).

Episodes with financial crises. Of all the episodes that have concluded in the period 19702018, just over half of government debt accumulation episodes and 40 percent of private debt accumulation episodes were associated with financial crises (Figure 3). Most crises occurred well before the end of the debt accumulation episode. Crises were equally 
common in longer episodes (those lasting a decade or more) and shorter ones (lasting less than a decade). The most common form of crisis in debt accumulation episodes was a currency crisis, often combined with other types of crises. ${ }^{4}$ More than three quarters of debt accumulation episodes associated with crises (either government or private) had currency crises.

\subsection{Results}

The one-half of debt accumulation episodes that were associated with financial crises had considerably weaker macroeconomic outcomes than those that subsided without crises.

Government debt accumulation episodes. Government debt accumulation episodes that involved crises were typically associated with greater debt buildups, weaker economic outcomes, and higher vulnerabilities than non-crisis episodes (Figure 4, Table 3). In the episodes associated with financial crises, the government debt buildup was, statistically significantly, 14 percentage points of GDP larger after eight years than in non-crisis episodes. After eight years, GDP and GDP per capita in episodes with crises were around 10 percent lower than in episodes without a crisis; investment was 22 percent lower; and consumption was 6 percent lower. International reserves deteriorated more in episodes associated with crises than in non-crisis episodes, as governments drew down reserves in an effort to stem currency depreciation. Nevertheless, currencies depreciated, and shortterm debt could not be rolled over.

Private debt accumulation episodes. Over an eight-year period, private debt accumulation episodes associated with crises featured weaker GDP and GDP per capita (by about 6 percent); consumption (by 8 percent); and investment (by 15 percent; Figure 5; Table 4). Private debt episodes with crises also saw significantly more pronounced deteriorations in external positions, especially international reserves and external debt, than non-crisis episodes. Episodes associated with crises featured broadly stable real exchange rates, in contrast to non-crisis episodes which were accompanied by strong real exchange rate appreciation; this would be consistent with a more productive use of borrowed funds in non-crisis episodes.

Similarities. Regardless of the borrowing sector, rapid debt accumulation episodes with crises featured considerably worse macroeconomic outcomes and vulnerabilities than those not associated with crises. Both types of episodes associated with crises saw sharp rises in inflation than non-crisis episodes, as well as larger falls in international reserves. Fiscal and current account deficits widened in both types of episodes with crises but more in government debt accumulation episodes than in private debt episodes.

Combined government and private debt accumulation episodes with crises were accompanied by significantly weaker investment and consumption growth than solely-

\footnotetext{
${ }^{4}$ Some studies have derived estimates of the incidence of crises around private lending booms. Mendoza and Terrones (2012) find that the peaks of 20-25 percent of credit booms were followed by banking crises or currency crises and that 14 percent were followed by sudden stops in capital flows. Schularick and Taylor (2012) identify credit growth as a significant predictor of financial crises. World Bank (2016) estimates that about half of credit booms are followed by at least mild deleveraging. Borio and Lowe (2002); Claessens and Kose (2018); Dell'Ariccia et al. (2016); Enoch and OtkerRobe (2007); and Gourinchas, Valdes, and Landerretche (2001) discuss how lending booms increase vulnerability to financial crisis.
} 
private episodes. For episodes in which crises were avoided, combined episodes also featured slower overall growth than solely private debt accumulation episodes (Table 3)

Differences. Government debt episodes associated with crises tended to be more costly than private debt episodes associated with crises, with much larger shortfalls in output and investment growth, especially in the early years after a crisis. Government debt accumulation episodes were often accompanied by real exchange rate depreciation while private debt accumulation episodes were typically accompanied by an appreciation, in part reflecting domestic demand booms that supported asset prices and real appreciation. The difference may also reflect the fact that most of the government debt accumulation episodes occurred in the first half of the sample, when more countries had pegged exchange rates, which tended to be abandoned when crises hit.

\subsection{Robustness test}

An alternative dating algorithm was used as robustness test. The alternative definition of debt accumulation episodes is in line with the literature on credit booms. To control for financial development, the literature on private credit booms identifies credit booms as sizable deviations of credit-to-GDP ratios from their trend (Mendoza and Terrones 2008). Applying this approach here, a debt accumulation is identified as the period between the trough and the peak in the government or private debt-to-GDP ratio provided at some point during the period the deviation of the debt-to-GDP ratio exceeds one standard deviation from its Hodrick-Prescott-filtered trend.

While this approach identifies a larger number of episodes, three quarters of these episodes have overlapping peaks or troughs (two thirds have overlapping peaks) and most results are robust to this alternative definition (Table 5). The median episode lasts for 7 (government) to 8 (private) years and features a debt buildup of 11 (private) to 30 (government) percentage points of GDP. More than half of government debt episodes and about one-half of all debt episodes are associated with crises.

\section{Debt and financial crises}

The preceding section described countries' susceptibility to financial crises during episodes of rapid debt accumulation, with about half of the episodes associated with such crises. This section quantifies the effect of debt accumulation on the likelihood of financial crises using an econometric model.

\subsection{Literature review}

Causes of debt crises. Theories on sovereign debt crises and default are closely linked to the unwillingness or the inability of governments to service their debt. Early models are based on cost-benefit analyses: the government chooses to default if the benefits of not servicing its obligations outweigh the costs, such as reputational loss or a threat of cutoff from access to international markets (e.g. Eaton and Gersovitz 1981; Bulow and Rogoff 1989). The default decision therefore hinges on the willingness - rather than the abilityof governments to repay their debt based on an intertemporal optimization calculus. Also, as governments borrow during bad times to smooth consumption, these models imply that defaults do not occur during recessions, which is at odds with actual experience. 
Later modifications allow for defaults to take place during bad times by focusing on the inability of governments to commit to their future policies. Multiple equilibria thus arises in these self-reinforcing cycles; in one equilibrium, insolvency or illiquidity results in default, while in another equilibrium, the government manages to roll over its debt (e.g. Calvo 1988; Cole and Kehoe 2000).

Political institutions can also affect the government's incentive to repay its debt. The low credibility associated with a less stable political system, as reflected in lower sovereign ratings and more volatile interest rate spreads, increases the risk of the government failing to service its debt (e.g. Citron and Nickelsburg 1987; Cuadra and Sapriza 2008).

Debt and currency crises. In the first generation crisis models, motivated by the breakdown of the Bretton Woods system, excessive fiscal deficits financed by issuing money could induce a sudden speculative attack on a fixed or pegged currency (e.g. Krugman 1979; Flood and Garber 1984). The central bank could find itself losing foreign reserves quickly in a bid to defend the peg, and the fixed exchange rate regime finally collapses.

Rapid debt accumulation, especially if it results in a debt crisis, can also lead to a currency crisis. Following a sovereign default, creditors might refuse to lend and withdraw their capital from the economy on recessionary fears, thereby putting downward pressure on the exchange rate. In the second generation crisis models, following the collapse of the European Exchange Rate Mechanism, doubts about the government's willingness to maintain its fixed exchange rate regime could lead to multiple equilibria and generate selffulfilling prophecies, in which changes in policies in response to a possible speculative attack could translate into an actual attack and a currency crisis (e.g. Obstfeld and Rogoff 1986; Flood and Marion 2000).

Distress can also be transmitted in the opposite direction. In response to speculative pressure on their currency, policymakers may choose to defend the peg by raising shortterm interest rates to stop capital outflows. Rising interest rates, however, increase the risk of a sovereign debt default through two channels. First, they make future debt servicing more expensive. Second, they may cause aggregate demand to decline, leading to a decline in tax revenues and an increase in the fiscal deficit (Lahiri and Végh 2003).

If the government does not defend and exits the peg, it runs the risk of losing access to the international capital market after a currency devaluation. This could trigger financial panic and expectations of further depreciations. The government could be forced to continuously raise interest rates to stem these fears, and this again makes borrowing and rolling over its debt more expensive, thus confirming investors' default expectations (Chang and Velasco 1999).

In the so-called "original sin" phenomenon, EDMEs are usually unable to borrow from international capital markets in their own currencies and hence hold open foreign currency positions on their balance sheets (Eichengreen, Hausmann, and Panizza 2002; Jeanne 2003). In that case, a devaluation would weaken their balance sheets further.

Debt and banking crises. The third generation crisis models, largely motivated by the 1997-98 Asian financial crisis, tend to stress private sector balance sheet vulnerabilities and incorporate credit frictions and banking panics (e.g. Krugman 1999; Chang and 
Velasco 2000). Financial and corporate sectors may face liquidity shocks when financing long-term projects with short-term borrowing, as well as currency mismatches due to large foreign-denominated debt. This sets up the possibility of a twin crises - currency and banking - if balance sheets deteriorate rapidly with fluctuations in asset prices, including exchange rates.

Vulnerabilities stemming from large borrowing by banks, in part induced by explicit or implicit government guarantees to bail out failing banks, can trigger crises and be selffulfilling due to fiscal concerns and volatile exchange rate movements (Burnside, Eichenbaum, and Rebelo 2004). Large sovereign exposures can limit banks' ability to extend loans to the private sector, hence triggering a credit crunch (Gennaioli, Martin, and Rossi 2014). Uncertainty following a debt default may also lead to a deposit run or a collapse of interbank markets (Borenzstein and Panizza 2008). An initial bank run can turn into self-fulfilling cycles of deposit withdrawals, liquidity shortages, and credit crunches (Diamond and Dybvig 1983).

Conversely, bank rescue operations, such as public recapitalization or the materialization of public guarantees and contingent liabilities, may impair the sustainability of public finances thus aggravating the feedback loop from the banking sector to the sovereign (Acharya, Drechsler, and Schnabl 2014). Banking crises may also ignite a currency crash, especially if the central bank monetizes to finance bailouts, thus increasing the risk of the government failing to repay its foreign currency debt (Reinhart and Rogoff 2011).

\subsection{Methodology}

Econometric framework. Studies on the determinants of crises are closely related to early warning system models. Prior early warning models were aimed at predicting currency crises following frequent crashes and devaluations in the 1980s and 1990s and they largely focused on macroeconomic and financial imbalances (e.g. Eichengreen, Rose, and Wyplosz 1995; Frankel and Rose 1996; Kaminsky and Reinhart 1999). Balance sheet variables became more prominent in later early warning models, especially in predicting banking crises (e.g. Demirgüç-Kunt and Detragiache 1998; Borio and Lowe 2002; Rose and Spiegel 2012). Studies on predicting sovereign debt crises emphasize the importance of solvency and liquidity measures, as well as factors that explain currency crises (e.g. Manasse, Roubini, and Schimmelpfenning 2003; Dawood, Horsewood, and Strobel 2017).

The most common estimation methods used in the empirical literature on predicting crises are logit and probit models. The baseline specification used in this study is a panel logit model with random effects, but for robustness purposes, a random effects probit model and a fixed effects logit model are also used. The Hausman test suggests that the random effects model is appropriate for debt and banking crises but not for currency crises. However, even for currency crises, the coefficient estimates and their statistical significance remain similar in fixed effects and random effects models.

To exploit the time and cross-sectional dimensions, a panel dataset of 139 EMDEs with annual data over the period 1970-2018 is constructed. The basic structure of the model takes the form: 


$$
Y_{i, t}=\beta^{\prime} X_{i, t-1}+\mu_{i}+\varepsilon_{i, t}
$$

where $Y_{i, t}$ is a crisis indicator (either sovereign debt, banking, or currency crisis) for country $i$ in year $t$, and takes the value of 1 if it is in a crisis, and 0 otherwise; $X_{i, t}$ is the vector of determinants of a crisis; $\beta$ is the vector of coefficient estimates common across all countries; $\mu_{i}$ captures the unobserved country heterogeneity; and $\varepsilon_{i, t}$ is the stochastic error term.

The probability of a crisis is given by:

$$
\operatorname{Pr}\left(Y_{i, t}=1 \mid X_{i, t-1}, \beta, \mu_{i}\right)=\Psi\left(\mu_{i}+\beta^{\prime} X_{i, t}\right)
$$

where assumptions about the distribution of the error terms, that is, the form of $\Psi($. renders the estimation of the logit (logistic distribution) or probit (normal distribution) discrete choice panel data model. The parameters can be estimated by maximizing the panel-level likelihood function.

Selection of explanatory variables. The variables are chosen from the empirical findings from the early warning crisis literature. ${ }^{5}$ This literature has identified the following correlates of higher crisis probabilities:

- Factors that increase rollover risk. These are particularly relevant during periods of elevated financial stress; they include high short-term external debt and high or rapidly growing total, government or private debt.

- Factors that restrict policy room to respond: These include low international reserves, large fiscal or current account deficits, and weak institutions.

- Factors that suggest overvaluation of assets. These indicate potential for large asset price corrections; they include exchange rate misalignments, and credit and asset price booms.

We include a large number of variables (and various data transformations, such as levels, growth rate, percentage point change, deviation from trend) that can be characterized into several groups:

- Debt profile: public debt, private debt, short-term debt, variable interest rate debt, concessional debt, multilateral debt, commercial debt, IMF credit, debt service

- Capital account: international reserves, currency mismatch, portfolio flows, FDI

- Current account: current account balance, exchange rate overvaluation, exchange rate regime, terms of trade

- Foreign: U.S. interest rate, advanced economies' GDP growth

- Domestic macro: GDP growth, inflation, unemployment, fiscal balance

- Financial sector. credit to private sector, money supply, interest rate

- Banking sector. liquidity, leverage, banking concentration, non-performing loans

- Structural: trade openness, export diversification, capital account openness

\footnotetext{
5 See Kaminsky, Lizondo, and Reinhart 1998; Frankel and Saravelos 2012; Chamon and Crowe 2012; and Moreno Badia et al. 2020 for an extensive review.
} 
- Institutional: governance, conflict, political stability

Some variables had low cross-country coverage and/or limited time series availability (especially banking sector and institutional quality indicators), and thus had to be dropped. To attenuate potential endogeneity bias due to contemporaneous interaction between economic fundamentals and crises, lagged values of the explanatory variables are used, except for the U.S. interest rate.

Of these potential correlates, the baseline regression model identifies several that are statistically significant and robust correlates of the probability of financial crises. The variables used in the baseline model (panel logit random effects model) are listed in Appendix 4 and the estimation results are summarized in Table $6 .{ }^{6}$ These include higher external vulnerabilities (higher short-term debt, higher debt service, and lower international reserves), adverse shocks (higher U.S. interest rates, lower domestic output growth), and faster debt accumulation - especially if true of both government and private debt. These findings are broadly consistent with the literature on leading indicators of financial crises, particularly with regard to the important roles of the composition of debt and pace of debt accumulation. ${ }^{7}$

\section{Results}

Probability of crises. The probability of crises occurring are evaluated at specific points of interest for illustration (while keeping all other variables at their average values), which include crisis episodes such as Mexico's 1982 twin crises. The findings are summarized in Table 7. For reference, 1.4 percent, 2.5 percent, and 4.2 percent of the observations in the sample are debt, banking, and currency crises, respectively. The regressions here suggest that combined private and government debt buildups significantly increase the probability of a currency crisis.

Debt accumulation. An increase in debt, either government or private, was associated with significantly higher probabilities of crisis in the following year. For example, an increase of 30 percentage points of GDP in government debt over the previous year (equivalent to the median buildup during a government debt accumulation episode) increased the probability of entering a sovereign debt crisis to 2.0 percent (from 1.4 percent) and that of entering a currency crisis to 6.6 percent (from 4.1 percent). For private debt, a 15 percentage point of GDP increase in debt (equivalent to the median increase during a private debt accumulation episode) doubled the probability of entering a banking crisis to about 4.8 percent, and the probability of a currency crisis to 7.5 percent, in the following year - probabilities considerably larger than those for a similarlysized buildup in government debt.

Combined government and private debt accumulation. Simultaneous increases in both government and private debt increased the probability of a currency crisis. Thus, a 15

\footnotetext{
${ }^{6}$ These include twin crises, defined as the simultaneous occurrence of any two types of financial crises (sovereign debt, banking, or currency). Such episodes are usually associated with much larger changes in typical leading indicators. The correlates in the baseline model indeed have higher statistical significance in predicting twin crises than individual crises.

${ }^{7}$ Relevant empirical regularities are reported in, for example, Moreno Badia et al (2020) and Manasse, Roubini, and Schimmelpfenning (2003) on sovereign debt crises; Kaminsky, Lizondo, and Reinhart (1998) on currency crises; and Kauko (2014) on banking crises.
} 
percentage point of GDP increase in private debt together with a 30 percentage point of GDP increase in government debt resulted in a 24 percent probability of entering a currency crisis the next year-more than six times the probability had debt remained stable (3.9 percent) and about one-third more than similarly-sized government or private debt buildups separately.

\section{The role of shocks and vulnerabilities}

Adverse shocks. Compared to average output growth outside crises (4 percent), growth in crisis episodes averaged -1 percent. Contractions of this magnitude increased the probability of entering a sovereign debt crisis in the subsequent year to 1.9 percent from 1.2 percent outside crisis episodes (Figure 6). A 2-percentage point increase in U.S. real interest rates - half of the cumulative increase during a typical tightening phase of U.S. monetary policy - increased the probability of entering a currency crisis by almost onehalf to 6.0 percent from 4.1 percent.

External vulnerabilities. A larger share of short-term debt in external debt, greater debt service cost, and lower reserve cover were associated with higher probabilities of financial crises.

Short-term debt. Compared to the probability of a sovereign debt crisis of 1.2 percent associated with a share of short-term debt of 10 percent of external debt (the average during non-crisis episodes), a 30 percent share of short-term debt in external debt (Mexico's share before it plunged into a twin currency and debt crisis in 1982) raised the probability of entering a sovereign debt crisis in the following year to 2.0 percent.

Debt service. A 50 percent ratio of debt service to exports-Mexico's average debt service burden in the early 1980s - was associated with probabilities of entering a sovereign debt crisis of 2.8 percent and a banking crisis of 5.5 percent. This was more than double the probabilities associated with a 15 percent debt service-to-export ratio in the average noncrisis episode.

Reserve cover. The probability of a debt or banking crisis exceeded 3 percent, and that of a currency crisis 5 percent, for a reserve cover of 1 month of imports (which was the case in Mexico in the early 1980s) compared to probabilities of 0.6-2.0 percent for banking and debt crises, and 3.8 percent for currency crises, when reserve cover amounted to 4 months of imports (the average for non-crisis episodes).

Other vulnerabilities identified tended to be more specific to certain types of crises or borrowing sectors:

Wholesale funding. Higher wholesale funding by banks, proxied by the ratio of credit to deposits, was associated with a greater probability of a banking crisis but appears to have been largely unrelated to the probabilities of sovereign debt and currency crises.

Real exchange rate overvaluation. Real exchange rate overvaluation was associated with a higher probability of a currency crisis but tended to be largely unrelated to banking and sovereign debt crises (Dornbusch et al. 1995).

Concessional debt and FDI flows. A higher share of concessional debt, which consists of loans extended on more generous than commercial terms, was associated with a lower 
probability of a sovereign debt crisis but tended to be largely unrelated to banking and currency crises. Larger FDI inflows, a more stable form of finance than portfolio inflows, were associated with a lower probability of a currency crisis.

Magnitude of crisis probabilities. In isolation, some of these probabilities appear small. This is expected since they are based on a sample in which crises are rare (less than 5 percent of observations) and they are associated with individual indicators. However, the probabilities could cumulate rapidly when multiple indicators deteriorate at the same time as has frequently happened prior to financial crises.

Twin crisis probabilities. The probability of the occurrence of twin crises (any two of sovereign debt, banking, and currency crises) is lower than single crisis events (in line with the less than 0.5 percent of the observations with twin or triple crises in the sample). A twin crisis is defined as the occurrence of any two of sovereign debt, banking, or currency crises within two consecutive years. However, the explanatory variables in the baseline model have better predictive ability in predicting a twin crisis one year ahead than in predicting a single crisis. An adverse GDP growth shock, a larger share of shortterm debt, higher debt service burden, lower reserve cover, and larger changes in government and private debt significantly increase the probability of a twin crisis, although the interaction term of government and private debt is insignificant. The estimation results are shown in Table 8.

\subsection{Robustness tests}

Several additional correlates were added to the baseline empirical specification to test the robustness of the results. The baseline results are robust to these alternative specifications. These results are provided in Tables 9 and 10 .

First, the quality of institutions may affect the incidence of crises. However, data for meaningful cross-country and over-time comparison, such as the Worldwide Governance Indicators (WDI; Kaufmann, Kraay and Mastruzzi 2010), is only available starting in the early 1990s. As a result, most sovereign debt and banking crises as well as many currency crises, which mainly occurred during the 1970s-1980s, will be omitted from the estimation sample. Indeed, the use of WDI data reduces the number of observations by almost a half. Furthermore, most measures of institutional quality are insignificant, while the results on other variables are broadly of the same magnitude, signs and significance as in the baseline specification. Several statistically significant results are counterintuitive and may reflect other omitted factors.

Second, to account for possible nonlinearity of the impact of debt increases on the probability of crises and its dependence on the level of debt, baseline regressions were augmented with squared changes in debt and interactions between a change in debt and the initial level of debt. In most specifications, these new variables are not statistically significant, while other coefficients remain consistent with the findings of the baseline model.

Third, the foreign exchange regime or a shift in foreign currency regime influence the probability of financial distress but in different ways for different types of crises. An EMDE with a fixed exchange rate is more likely to suffer a sovereign debt crisis, while a shift to a flexible exchange rate increases the likelihood of a banking crisis. A currency 
crisis is more likely if a shift to a flexible exchange rate regime occurred the year before the crisis. Other regression coefficients remain consistent with the baseline specification regardless of the exchange rate regime.

\section{Selected country case studies}

The preceding section quantified how shocks and vulnerabilities have affected the likelihood of crises. However, in addition to these factors, other structural and institutional weaknesses may make an economy more prone to crises once an adverse shock strikes. These weaknesses are explored in this section in a set of selected country case studies of financial crises, which complements and expands on the earlier analysis.

This section focuses on macroeconomic policies, and structural and institutional features that relate to shortcomings in financial sector supervision and corporate governance. It also identifies other factors, including political uncertainty, balance sheet mismatches, heavily managed exchange rates, state-led growth models, heavy presence of state-owned enterprises, less diversified economies, and implicit sovereign guarantees. Individual aspects of these have been widely discussed in the literature. ${ }^{8}$

\subsection{Methodology}

The case studies focus on 43 crisis episodes in 34 EMDEs that have witnessed rapid government or private debt accumulation since 1970. Most of these cases (65 percent) involved overlapping private and government debt accumulation episodes. Almost all cases (90 percent) involved two crises, and 40 percent involved three crises. While nonexhaustive, the case studies were selected by the following criteria. First, they are representative of debt accumulation episodes over the past fifty years. Second, they include a broad range of EMDEs, including both large EMDEs in major regional debt crises episodes and LICs. Third, they have been sufficiently examined in earlier studies for a general assessment about their causes and consequences to be reached with confidence. Appendix 5 summarize four of these examples in more detail.

For each of the cases examined, earlier work-IMF Article IV consultation reports, academic studies, and policy papers - provides a wealth of information on the structural features and institutional background. The main references for the country case studies that are specifically referred to in the section are listed in Appendix 6. In general, IMF Article IV reports were the primary sources of information.

\footnotetext{
${ }^{8}$ For a discussion of some of these macroeconomic, structural and institutional shortcomings see Balassa (1982); Kaufmann (1989); and Sachs $(1985,1989)$ on growth strategies and uses of debt; Roubini and Wachtel (1999) on current account sustainability; Daumont, Le Gall, and Leroux (2004) and Kawai, Newfarmer, and Schmukler (2005) on inadequate banking regulation; Brownbridge and Kirkpatrick (2000) on balance sheet mismatch; and Capulong et. al. (2000) for poor corporate governance.
} 


\subsection{Results}

\section{Macroeconomic factors}

Inefficient use of debt. Many EMDEs made inefficient use of debt. In the 1970s-80s, public debt was used for import substitution policies in some countries, particularly in LAC (e.g. Argentina, Brazil, Venezuela; Balassa 1982). Public debt was also used in some countries to finance current government spending and populist policies which led to overly expansionary macroeconomic policies (Argentina, Brazil, Chile, Peru). In other countries, rapid private-sector borrowing resulted in debt-fueled domestic demand booms, including property booms (Thailand, Ukraine) or inefficient manufacturing investment (Korea).

Inadequate fiscal management. Many countries had severe fiscal weaknesses. These included weak revenue collection (Argentina, Brazil, Indonesia, Russia), widespread tax evasion (Argentina, Russia), public wage and pension indexing (Argentina, Brazil, Mexico, Uruguay), monetary financing of fiscal deficits (Argentina, Brazil), and substantial use of energy and food subsidies (Egypt, Venezuela).

Risky composition of debt. Many of the crisis countries borrowed in foreign currency. They struggled to meet debt service obligations and faced steep jumps in debt ratios following currency depreciations (Indonesia, Mexico, Thailand). In Uruguay, for example, almost all public debt was denominated in U.S. dollars in the mid-1990s. Several countries relied on short-term borrowing and faced rollover difficulties when investor sentiment deteriorated (Indonesia, Korea, Philippines, Russia in the late 1990s). In Europe and Central Asia (ECA) in the 2000s, countries borrowed cross-border from nonresident lenders and faced a credit crunch once liquidity conditions tightened for global banks that were the source of this lending (Croatia, Hungary, Kazakhstan in the late 2000s).

Balance sheet mismatches. A substantial number of currency and banking crises, and the majority of concurrent currency and banking crises, were associated with balance sheet mismatches (Indonesia, Malaysia, Mexico, and Russia in the late 1990s). Sovereign debt crises less frequently involved balance sheet mismatches, except when banking supervision was weak (Indonesia, Turkey in the 1990s).

Managed exchange rates. Many, but far from all, crises were associated with managed exchange rates. These tended to lead to currencies becoming overvalued during years of rapid growth, debt buildup, and capital inflows but eventually succumbed to speculative attacks (Brazil, Mexico, Slovak Republic).

\section{Structural and institutional features}

Poorly designed growth strategies. Many of the case studies of crises in the 1970s and early 1980s showed heavy state intervention through state-led industrialization, stateowned companies, and state-owned banks (Balassa 1982). Industrial policy in countries such as Argentina, Brazil, and Venezuela focused on import substitution industrialization, typically financed by external borrowing.

Lack of economic diversification. A number of the crisis countries had undiversified economies, which increased their vulnerability to terms of trade shocks. Several countries in Latin America and the Caribbean (LAC) and Sub-Saharan Africa (SSA), in particular, 
were heavily dependent on both oil and non-oil commodity exports (Bolivia, Niger, Nigeria, Paraguay, Uruguay in the 1970s and 1980s). When commodity prices fell in the 1980 s, the profitability of (often state-owned) corporates in the resource sector, fiscal revenues, and export proceeds collapsed, which triggered financial crises.

Inadequate banking regulation. Poor banking regulation was a common feature in many case studies. Several SSA countries experienced banking crises in the 1980s primarily because of the failure of banks that were typically state-owned and subject to little oversight (Cameroon, Kenya, Niger, and Tanzania). In EAP, financial deregulation contributed to insufficient regulation and oversight of the financial sector in the 1990s (Indonesia, Korea, Malaysia, Philippines, and Thailand). This resulted in growing weaknesses, including balance sheet mismatches, and excessive risk taking by corporates (see below). In several countries in ECA during the 2000s, cross-border lending was inadequately regulated by domestic regulators (Croatia, Hungary, and Kazakhstan).

Poor corporate governance. Among case studies of the 1980s and 1990s, poor corporate governance was a common shortcoming, notably in some East Asian countries (Indonesia, Korea, and Thailand). Along with poor bank regulation, this led to inefficient corporate investment, as banks lent to firms without rigorously evaluating their creditworthiness.

Political uncertainty. Many sovereign debt crises were associated with severe political uncertainty (Indonesia, Philippines, Turkey, Venezuela).

\section{Triggers of crises}

Case studies suggest that crises were usually triggered by external shocks, although in a small number of countries domestic factors also played a role.

External shocks. The most common triggers of crises were external shocks to the real economy. These included a sudden rise in global interest rates (LAC in the 1980s), a slowdown in global growth (ECA in the 2000s), a fall in commodity prices for commodity exporting economies (LAC and SSA in the 1980s, Russia in the 1990s), and contagion from both global crises (2007-09 global financial crisis) and regional crises (Asian financial and Russian crises in the 1990s), which generated sudden withdrawals of capital inflows.

Natural disasters. Natural disasters such as droughts were a major contributing factor to crises in some countries, typically smaller, less diversified economies (Bangladesh in the 1970s, Nepal in the 1980s, Zimbabwe in the 2000s).

Other domestic shocks. In a small number of countries, crises were triggered, or exacerbated, by other domestic shocks. Typically, these were episodes of political turmoil (Turkey, Zimbabwe).

\section{Resolution of crises}

Many, though not all, crises were resolved by policy programs of adjustment and structural reform supported by financing from the IMF, World Bank, and other multilateral bodies and partner countries.

IMF support and reforms. The vast majority of countries in these case studies adopted IMF-supported policy programs to overcome their crises. The countries that did not use 
IMF support typically had stronger fundamentals, including lower public debt and larger international reserves (Colombia, Kazakhstan, Malaysia). IMF support was conditional on the implementation of macroeconomic and structural reforms. For many EMDEs in LAC in the 1980s and in EAP in the 1990s, crises were the trigger for policy changes to allow greater exchange rate flexibility and strengthen monetary policy regimes.

Debt restructuring. Among the case studies of sovereign debt crises, many ended with default and restructuring of debt (Argentina, Cameroon, Mexico, Nigeria). These cases were more common in the 1980s, 1990s, and early 2000s. Debt restructuring was often prolonged and occurred well after the initial sovereign debt crisis.

\section{Conclusion}

Episodes of rapid debt accumulation have been common in EMDEs, and around half of these were associated with financial crises. In episodes associated with crises, output, investment, and consumption were lower than in non-crisis episodes, with government debt buildups experiencing worse outcomes than private debt buildups.

When they occurred, financial crises were typically triggered by external shocks, but in some instances also by domestic factors. When these shocks occurred, larger or more rapidly growing debt constituted a vulnerability that increased the likelihood of a country sliding into crisis. In addition, external vulnerabilities, such as a larger share of short-term debt, higher debt service cost, and lower reserve cover, increased the probability of crisis. Most countries that slid into crises also suffered from inadequate fiscal, monetary, and financial sector policies.

The results highlight the critical role of strong institutional frameworks that can reduce the likelihood and the impact of crises. These include robust financial regulation and supervision, fiscal frameworks that credibly maintain sustainability, and monetary policy frameworks and exchange rate regimes geared toward macroeconomic stability. In addition, the paper shows that the likelihood of crises can be reduced by ensuring a resilient composition of debt. Debt denominated in local currency and at long maturities is less prone to market disruptions than foreign-currency or short-term debt.

There are several avenues for future research. First, the event study could be extended by taking a more granular approach to the drivers of an increase in the debt-to-GDP ratio (e.g. differentiating between a rise in nominal debt vs. fall in GDP). Second, while a large literature explores the roles of various vulnerabilities, including debt composition, in financial crises, there is limited analysis of the role of institutional weakness. Future research could examine in greater depth how specific institutional frameworks, such as fiscal rules, inflation targeting or robust financial supervision and regulation, can reduce the frequency and impact of crises. Finally, an in-depth assessment of debt crises triggered by problems related to debt transparency, such as the revelation of hidden debt or the realization of contingent liabilities, including from state owned enterprises, public-private partnerships, subnational borrowing, collateralized lending or other explicit and implicit lending guarantees. 
Figure 1. Country examples of debt accumulation episodes

\section{A. Turkey: Government debt}

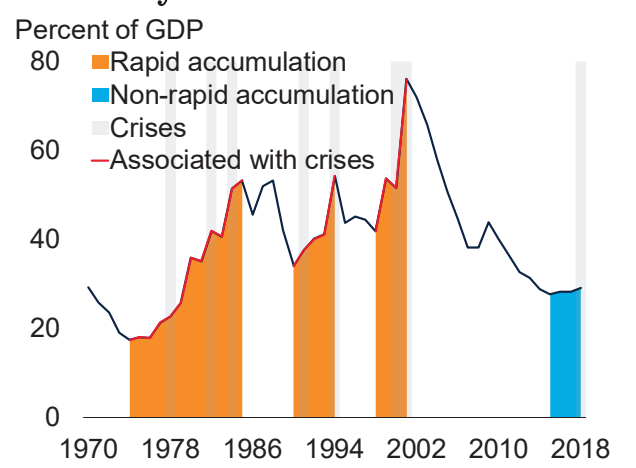

C. Philippines: Private debt

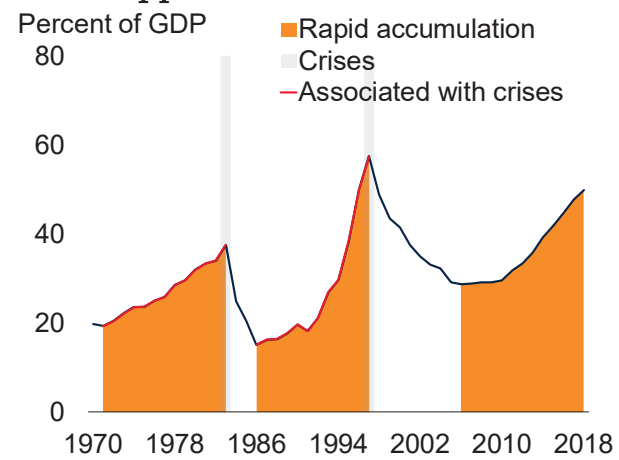

B. Mexico: Government debt

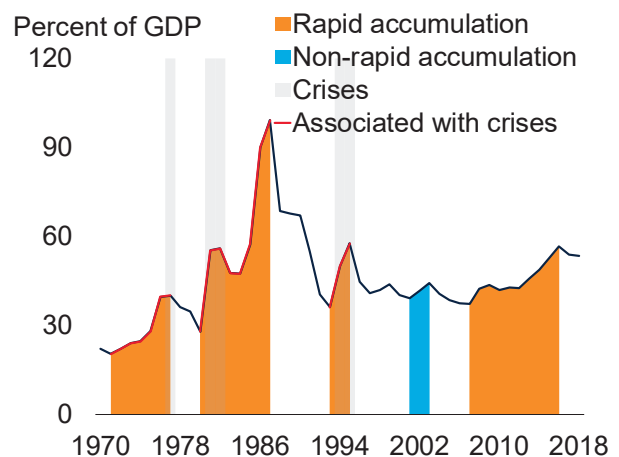

D. Malaysia: Private debt

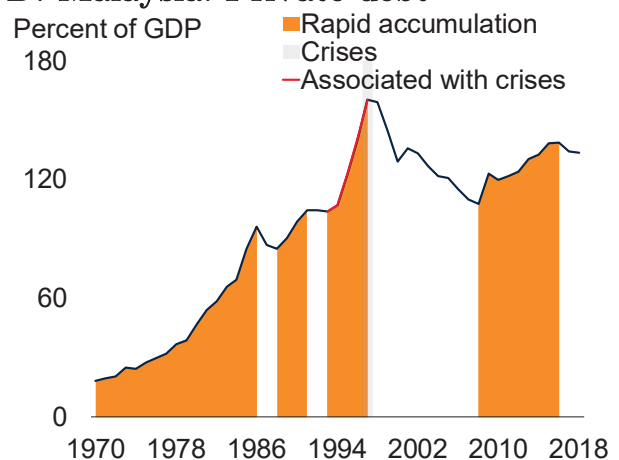

Sources: International Monetary Fund, World Bank.

Note: Blue line indicates debt outside debt accumulation episodes. A period of debt accumulation is identified with the algorithm in Harding and Pagan (2002). When a change in debt-to-GDP ratios over an accumulation period is above the maximum of 10-year moving standard deviation of the ratios during the period, it is considered as a rapid debt accumulation (shown as an orange area). When it is below the threshold, it is treated as a non-rapid accumulation (shown as a light blue area). If a crisis (i.e., banking, currency, or debt crisis) occurs during a rapid debt accumulation period or within two years since the end of the period, it is regarded as an episode of rapid debt accumulation associated with a crisis (shown as a red line). An ongoing episode (e.g., the third orange area in Panel C) is also classified as either rapid or non-rapid accumulation, based on the same methodology. 
Figure 2. Episodes of rapid debt accumulation in EMDEs

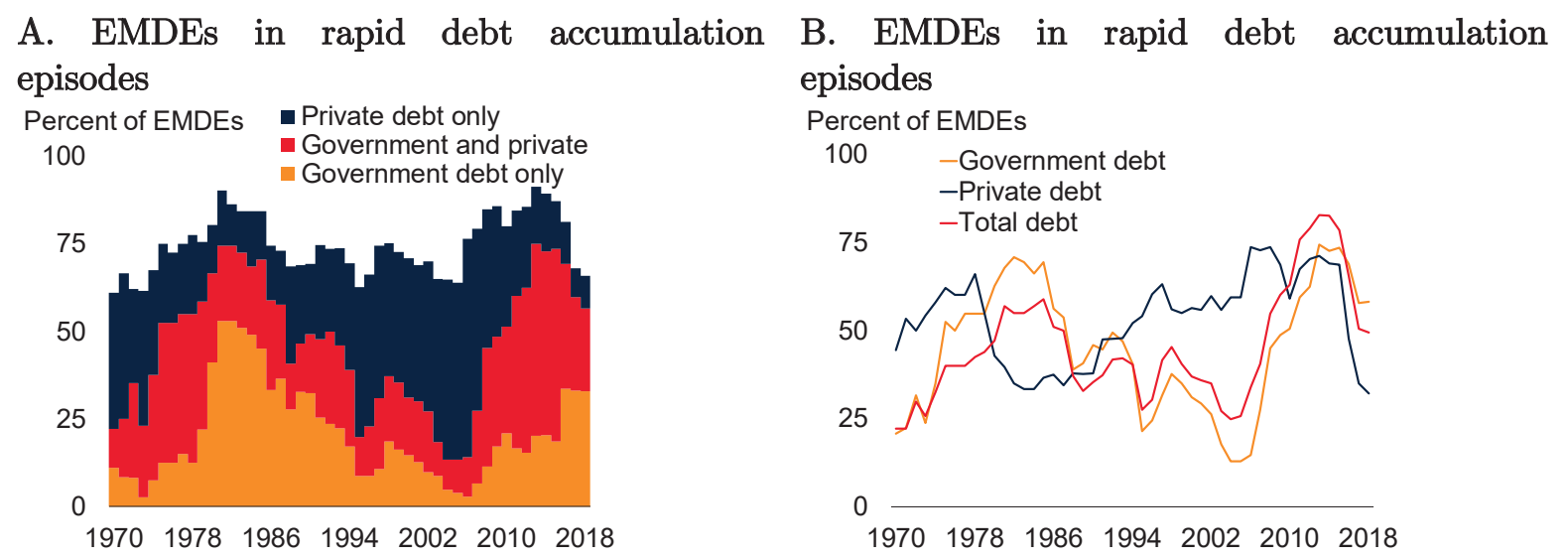

C. Duration of rapid debt accumulation episodes

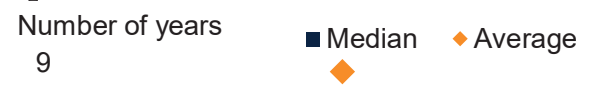

D. Change in debt during rapid accumulation episodes

Percentage points of GDP

60
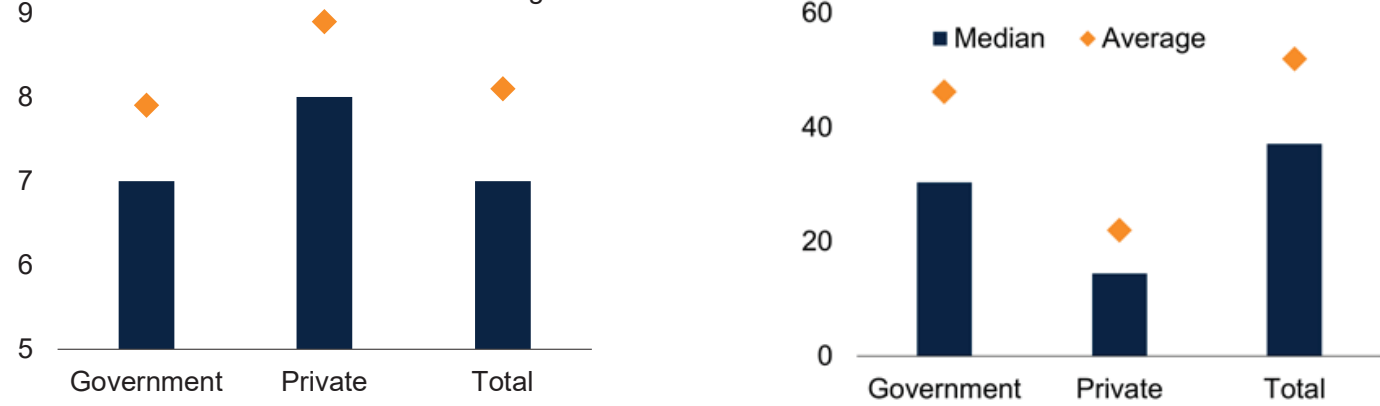

Source: International Monetary Fund; World Bank.

A.B. Figures show the share of EMDEs in the sample that are in rapid debt accumulation episodes.

C.D. Figures show the duration and magnitude of rapid debt accumulation episodes. 
Figure 3. Crises during rapid debt accumulation episodes in EMDEs

$\begin{array}{ll}\text { A. Government debt accumulation episodes } & \text { B. Private debt accumulation episodes } \\ \text { associated with crises } & \text { associated with crises } \\ \text { Percent of episodes } & \text { Percent of episodes }\end{array}$

60

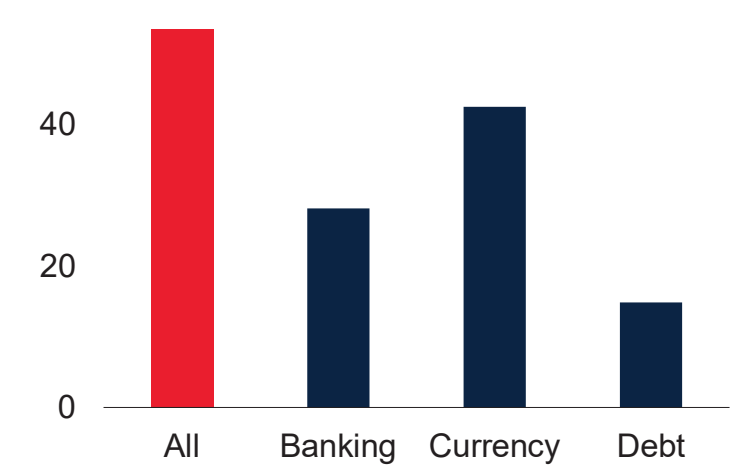

60

40

20

0

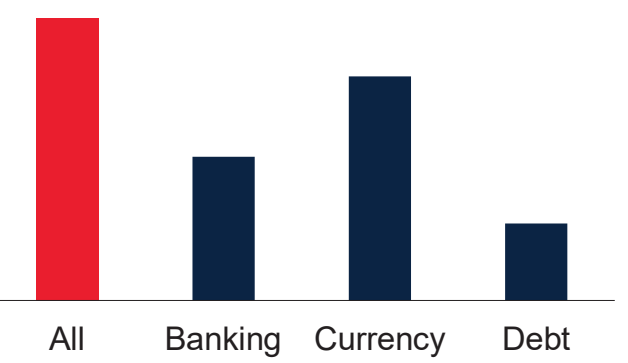

Source: International Monetary Fund; World Bank.

Note: Figures show the share of government and private debt accumulation episodes that ended in crises, both for all types of crises, and for individual types of crises. 
Figure 4. Macroeconomic developments during government debt accumulation episodes

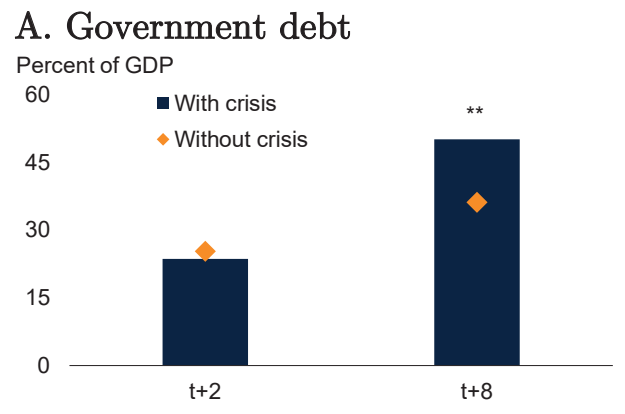

C. Investment and consumption

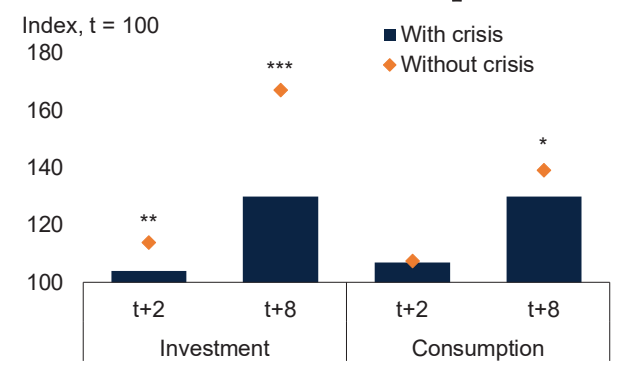

B. Output and per capita output

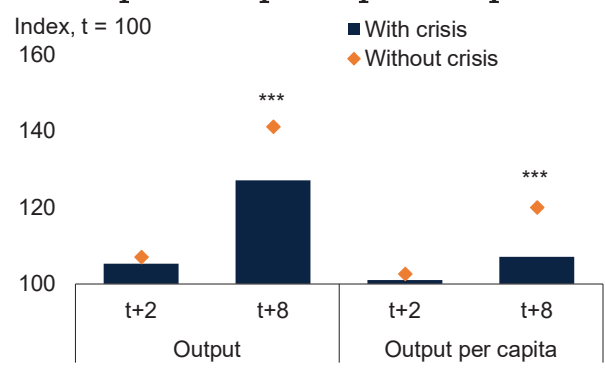

D. International reserves and external debt

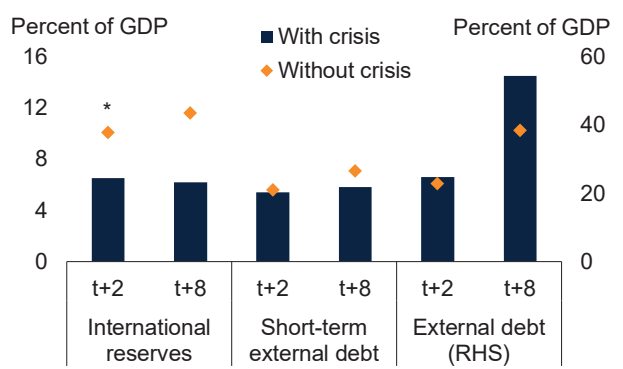

Source: International Monetary Fund, World Bank.

Note: Figures show the median evolution of macroeconomic variables in debt accumulation episodes with data available for at least 8 years from the beginning of the episode. Year "t" refers to the beginning of rapid government debt accumulation episodes. All variables are scaled to 100 at $\mathrm{t}=0$. Episodes associated with crises are those experience financial crises (i.e., banking, currency, and debt crises, as in Laeven and Valencia 2018) during or within two years after the end of episodes. ${ }^{* *}$, and ${ }^{* * *}$ denote that medians between episodes associated with crises and those with no crises are statistically different at 10 percent, 5 percent, and 1 percent levels, respectively, based on Wilcoxon rank-sum tests.

A. Government debt in percent of GDP two and eight years after the beginning of the government debt accumulation episode (t).

B.C. Based on real growth rates for output, output per capita, investment and consumption. 
Figure 5. Macroeconomic developments during private debt accumulation episodes

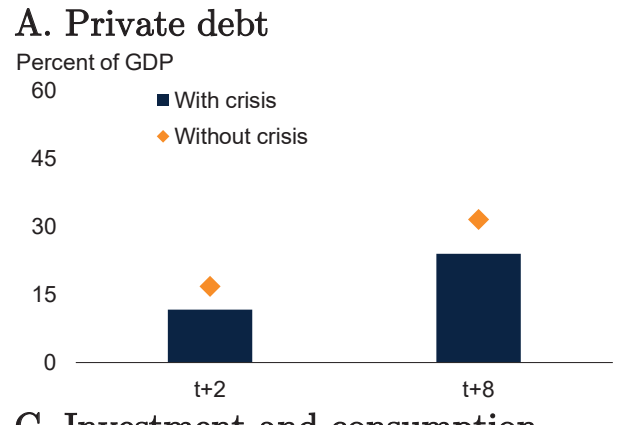

C. Investment and consumption Index $\mathrm{t}=100$

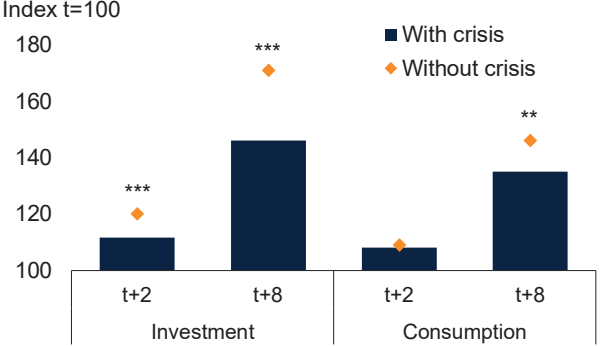

\section{B. Output and per capita output}

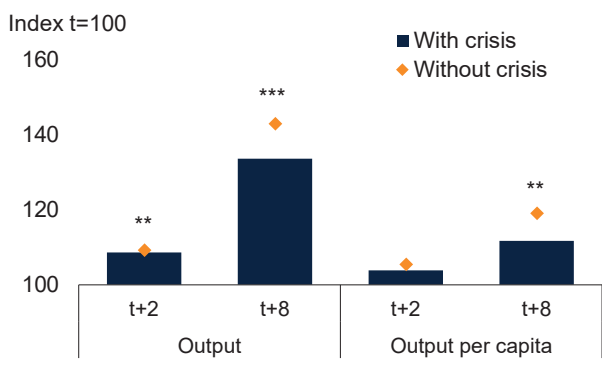

D. International reserves and external debt

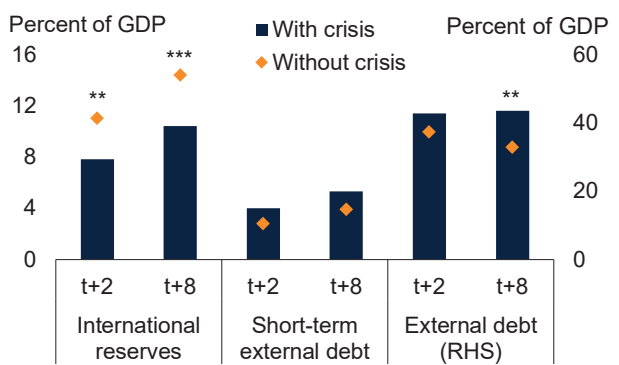

Source: International Monetary Fund; Laeven and Valencia (2018); World Bank.

Note: Figures show the median evolution of macroeconomic variables in debt accumulation episodes with data available for at least 8 years from the beginning of the episode. Year "t" refers to the beginning of rapid private debt accumulation episodes. Episodes associated with crises are those that experienced financial crises (banking, currency, and debt crises, as in Laeven and Valencia (2018)) during or within two years after the end of episodes. "**, "***, and "***" denote that medians between episodes associated with crises and those with no crises are statistically different at 10 percent, 5 percent, and 1 percent levels, respectively, based on Wilcoxon rank-sum tests.

A. Private debt in percent of GDP two and eight years after the beginning of the government debt accumulation episode $(\mathrm{t})$.

B.C. Based on real growth rates for output (GDP), output (GDP) per capita, investment and consumption. 
Figure 6. Predicted crisis probabilities

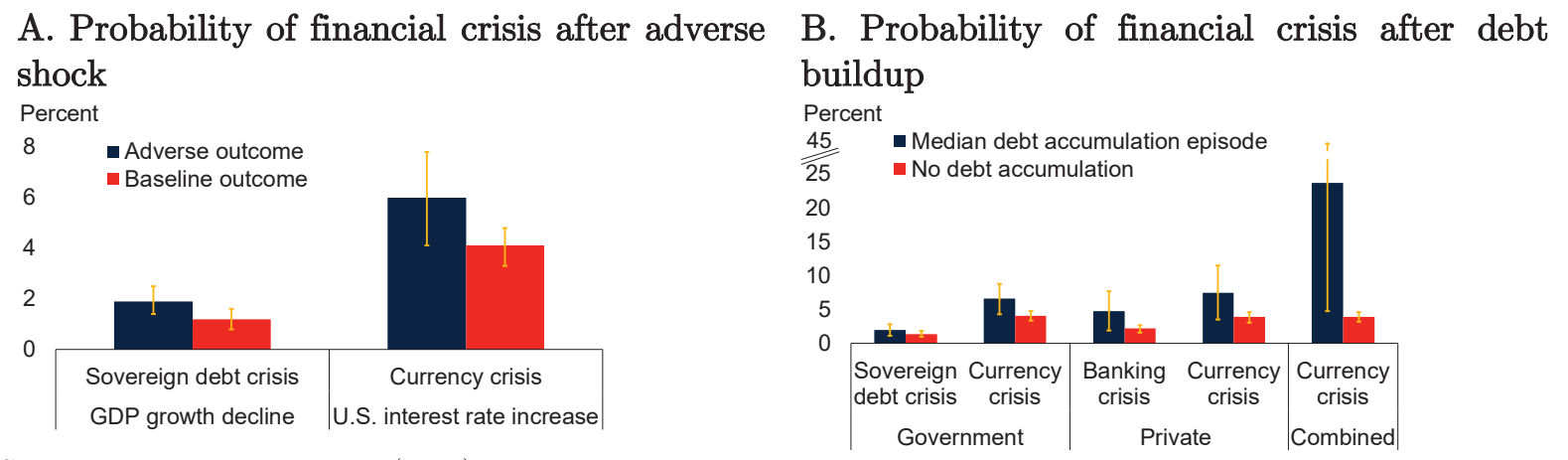

Source: Laeven and Valencia (2018); World Bank.

Note: Figures show the predicted probability of currency, banking, and debt crises (as defined in Laeven and Valencia (2018)) based on regression results. Whiskers indicate 95 percent confidence intervals.

A. "Adverse outcome" is GDP growth of -1 percent (average EMDE growth during crisis episodes) or U.S. policy interest rate increase of 2 percentage points (cumulative U.S. Fed Funds rate increase from end-2015 to mid-2018). "Baseline outcome" is GDP growth of 4 percent (average EMDE growth outside crisis episodes) and no U.S. policy interest rate increase.

B. Predicted probabilities assuming government debt buildup of 30 percentage points of GDP or private debt buildup of 15 percentage points of GDP or both in the median debt accumulation episode. 
Table 1. Duration and amplitude of rapid debt accumulation episodes

Duration

\begin{tabular}{|c|c|c|c|c|c|c|c|}
\hline & \multirow[b]{3}{*}{ Years: } & \multicolumn{6}{|c|}{ Number of episodes, by duration (years) } \\
\hline & & \multicolumn{3}{|c|}{ Associated with crises } & \multicolumn{3}{|c|}{ No crises } \\
\hline & & $2-4$ & $5-10$ & $11-$ & $2-4$ & $5-10$ & $11-$ \\
\hline Government debt & & 41 & 59 & 37 & 27 & 74 & 18 \\
\hline Private debt & & 27 & 39 & 39 & 37 & 83 & 38 \\
\hline Total debt & & 31 & 40 & 35 & 29 & 78 & 24 \\
\hline
\end{tabular}

\section{Amplitude}

\begin{tabular}{|c|c|c|c|c|c|c|c|c|}
\hline \multirow[b]{3}{*}{ Percentage points of GDP: } & \multicolumn{8}{|c|}{ Number of episodes, by amplitude (percentage points of GDP) } \\
\hline & \multicolumn{4}{|c|}{ Associated with crises } & \multicolumn{4}{|c|}{ No crises } \\
\hline & -20 & $20-40$ & $40-60$ & $60-$ & -20 & $20-40$ & $40-60$ & $60-$ \\
\hline Government debt & 24 & 41 & 24 & 48 & 53 & 40 & 16 & 10 \\
\hline Private debt & 66 & 17 & 13 & 9 & 97 & 48 & 11 & 2 \\
\hline Total debt & 9 & 32 & 26 & 39 & 33 & 57 & 20 & 21 \\
\hline
\end{tabular}

Note: Total debt refers to the sum of government debt and private debt. A period of debt accumulation is identified with the algorithm in Harding and Pagan (2002). When a change in debt-to-GDP ratios over an accumulation period is above the maximum of 10-year moving standard deviation of the ratios during the period, it is considered as a rapid debt accumulation. The duration of episodes refers to the number of years from trough to peak debt-to-GDP ratios. The amplitude refers to the size of the increase in debt-to-GDP ratios over the same period. 
Table 2. Comparison of combined episodes with single episodes

\begin{tabular}{|c|c|c|c|c|c|c|}
\hline & \multicolumn{3}{|c|}{ Rapid accumulation with crises } & \multicolumn{3}{|c|}{ Rapid accumulation without crises } \\
\hline & $\begin{array}{r}\text { Government } \\
\text { debt }\end{array}$ & $\begin{array}{r}\text { Private } \\
\text { debt }\end{array}$ & $\begin{array}{r}\text { Both } \\
\text { (combined) }\end{array}$ & $\begin{array}{r}\text { Government } \\
\text { debt }\end{array}$ & $\begin{array}{r}\text { Private } \\
\text { debt }\end{array}$ & $\begin{array}{r}\text { Both } \\
\text { (combined) }\end{array}$ \\
\hline Duration (years) & 7 & 8 & 3 & 7 & 8 & 4 \\
\hline Amplitude (percentage points of GDP) & 43 & 13 & 35 & 22 & 15 & 26 \\
\hline Growth (percent) & 2.2 & 3.7 & 2.7 & 4.1 & 4.6 & 4.2 \\
\hline Per capita growth (percent) & 0.1 & 1.9 & 0.9 & 2.0 & 2.5 & 2.0 \\
\hline Investment growth (percent) & 1.9 & 5.7 & 2.2 & 6.3 & 7.2 & 6.1 \\
\hline Private consumption growth (percent) & 2.5 & 4.0 & 2.9 & 4.1 & 4.8 & 4.2 \\
\hline Reserves (percent of GDP) & 7.2 & 7.2 & 6.6 & 12.9 & 13.2 & 12.9 \\
\hline Short-term external debt (percent of GDP) & 4.4 & 4.8 & 4.3 & 3.9 & 3.7 & 3.8 \\
\hline
\end{tabular}

Note: A combined episode covers years with concurrent government and private debt accumulation episodes. Single episodes cover years with a solely-government debt accumulation episode or a solely-private debt accumulation episode. Amplitude for "Both (combined)" is measured as an average of amplitudes of government debt and private debt during a combined government and private debt accumulation episode. Bold numbers indicate statistically significant difference from combined episodes. 
Table 3. Robustness exercises: Government debt

\begin{tabular}{|c|c|c|c|c|c|c|c|c|}
\hline & \multicolumn{8}{|c|}{ Cumulative change in eight years from the beginning of rapid government debt accumulation } \\
\hline & \multicolumn{2}{|c|}{ Baseline } & \multicolumn{2}{|c|}{ Baseline (Mean) } & \multicolumn{2}{|c|}{ Advanced economies } & \multicolumn{2}{|c|}{ All countries } \\
\hline & Crises & No crises & Crises & No crises & Crises & No crises & Crises & No crises \\
\hline Output & 127 & 141 & 127 & 140 & 112 & 120 & 125 & 129 \\
\hline Per capita output & 107 & 120 & 108 & 116 & 106 & 116 & 107 & 117 \\
\hline Investment & 130 & 167 & 154 & 183 & 102 & 111 & 118 & 129 \\
\hline Private consumption & 130 & 139 & 131 & 138 & 111 & 119 & 125 & 126 \\
\hline Consumer price & 198 & 141 & 626 & 171 & 116 & 123 & 186 & 133 \\
\hline REER & 88 & 101 & 100 & 103 & 95 & 100 & 92 & 100 \\
\hline Current account balance & -28 & -25 & -30 & -28 & -7 & -7 & -26 & -19 \\
\hline Fiscal balance & -37 & -27 & -39 & -28 & -34 & -22 & -35 & -23 \\
\hline Reserves & 60 & 105 & 89 & 128 & 60 & 91 & 60 & 102 \\
\hline Total external debt & 402 & 365 & 460 & 458 & - & - & 402 & 365 \\
\hline Short-term external debt & 48 & 33 & 65 & 42 & - & - & 48 & 33 \\
\hline
\end{tabular}

Note: This table shows cumulative levels or shares of GDP in eight years since the beginning of rapid accumulation episodes (year "t") of government debt (Panel A) and private debt (Panel B). Output, per capita output, investment, private consumption, consumer price, REER, and debt-to-GDP ratio are presented as an index equal to 100 in year "t" while current account balance, fiscal balance, reserves, total external debt, and short-term external debt are in percent of GDP. "Baseline" shows medians; "Mean" shows average results; "Rolling window" uses 10-year moving standard deviations (over t-9 and t) to identify episodes; "Lower threshold" uses half of country-specific standard deviations; "Advanced economies" uses data for advanced economies. The numbers in bold show that differences between crises and non-crises are statistically significant at least at the 10 percent level. 
Table 4. Robustness exercises: Private debt

\begin{tabular}{|c|c|c|c|c|c|c|c|c|}
\hline & \multicolumn{8}{|c|}{ Cumulative change in eight years from the beginning of rapid private debt accumulation } \\
\hline & \multicolumn{2}{|c|}{ Baseline } & \multicolumn{2}{|c|}{ Baseline (Mean) } & \multicolumn{2}{|c|}{ Advanced economies } & \multicolumn{2}{|c|}{ All countries } \\
\hline & Crises & No crises & Crises & No crises & Crises & No crises & Crises & No crises \\
\hline Output & 133 & 143 & 135 & 147 & 123 & 128 & 130 & 139 \\
\hline Per capita output & 112 & 119 & 115 & 119 & 121 & 119 & 115 & 119 \\
\hline Investment & 146 & 171 & 174 & 245 & 139 & 132 & 142 & 156 \\
\hline Private consumption & 135 & 146 & 140 & 161 & 124 & 128 & 134 & 139 \\
\hline Consumer price & 211 & 145 & 440 & 163 & 138 & 132 & 195 & 141 \\
\hline REER & 99 & 109 & 105 & 112 & 106 & 104 & 102 & 108 \\
\hline Current account balance & -28 & -32 & -27 & -8 & -4 & -5 & -21 & -23 \\
\hline Fiscal balance & -28 & -18 & -33 & -10 & -26 & -18 & -27 & -18 \\
\hline Reserves & 65 & 112 & 82 & 173 & 55 & 71 & 61 & 105 \\
\hline Total external debt & 509 & 367 & 569 & 458 & - & - & 509 & 367 \\
\hline Short-term external debt & 50 & 38 & 70 & 54 & - & - & 50 & 38 \\
\hline
\end{tabular}

Note: This table shows cumulative levels or shares of GDP in eight years since the beginning of rapid accumulation episodes (year "t") of government debt (Panel A) and private debt (Panel B). Output, per capita output, investment, private consumption, consumer price, REER, and debt-to-GDP ratio are presented as an index equal to 100 in year "t" while current account balance, fiscal balance, reserves, total external debt, and short-term external debt are in percent of GDP. "Baseline" shows medians; "Mean" shows average results; "Rolling window" uses 10-year moving standard deviations (over t-9 and t) to identify episodes; "Lower threshold" uses half of country-specific standard deviations; "Advanced economies" uses data for advanced economies. The numbers in bold show that differences between crises and non-crises are statistically significant at least at the 10 percent level. 
Table 5. Robustness to alternative definition of episodes

\begin{tabular}{ccc}
\hline & \multicolumn{2}{c}{ Accumulation episodes } \\
\cline { 2 - 3 } & Government debt & Private debt \\
\hline \hline Number of episodes (count) & & \\
Baseline definition & 256 & 363 \\
Alternative definition & 325 & 362
\end{tabular}

Share of episodes in baseline and alternative definition (percent)

With same start or end year 71 76

With same end year

Median duration of episode (years)

Baseline definition 7

Alternative definition

Median amplitude of episode

(percentage points of GDP)

Baseline definition

Alternative definition

Note: In the baseline definition, an episode is defined as the increase in debt-to-GDP ratio from peak to trough, if the peak-to-trough increase exceeds one country-specific, ten yearrolling standard deviation. In the alternative definition, an episode is defined as the increase in debt-to-GDP ratio from peak to trough if during this period, the debt-to-GDP ratio exceeds its Hodrick-Prescott-filtered trend by one standard deviation at some point during the period from trough to peak debt-to-GDP ratio. 
Table 6. Random effects logit model

Dependent variable: Crisis indicator $(1=$ crisis, $0=$ no crisis $)$

\begin{tabular}{|c|c|c|c|}
\hline & Debt crisis & Banking crisis & Currency crisis \\
\hline Change in U.S. real interest rate & $\begin{array}{l}-0.067 \\
(0.132)\end{array}$ & $\begin{array}{c}0.015 \\
(0.106)\end{array}$ & $\begin{array}{l}0.253^{* *} \\
(0.100)\end{array}$ \\
\hline GDP growth & $\begin{array}{c}-0.095 * * * \\
(0.025)\end{array}$ & $\begin{array}{l}-0.020 \\
(0.025)\end{array}$ & $\begin{array}{l}-0.006 \\
(0.020)\end{array}$ \\
\hline Short-term debt & $\begin{array}{l}0.026^{*} \\
(0.015)\end{array}$ & $\begin{array}{c}0.012 \\
(0.012)\end{array}$ & $\begin{array}{c}0.006 \\
(0.011)\end{array}$ \\
\hline Debt service & $\begin{array}{c}0.028^{* * *} \\
(0.009)\end{array}$ & $\begin{array}{c}0.029^{* * * *} \\
(0.007)\end{array}$ & $\begin{array}{c}0.010 \\
(0.008)\end{array}$ \\
\hline Reserves cover & $\begin{array}{c}-0.573^{* * *} \\
(0.116)\end{array}$ & $\begin{array}{c}-0.163^{* * *} \\
(0.063)\end{array}$ & $\begin{array}{l}-0.115^{*} \\
(0.062)\end{array}$ \\
\hline Change in government debt & $\begin{array}{l}0.014^{*} \\
(0.008)\end{array}$ & & $\begin{array}{l}0.016^{* *} \\
(0.007)\end{array}$ \\
\hline Change in private debt & & $\begin{array}{l}0.055^{* *} \\
(0.023)\end{array}$ & $\begin{array}{l}0.052^{* *} \\
(0.026)\end{array}$ \\
\hline $\begin{array}{l}\text { Change in government debt } \\
\mathrm{x} \text { Change in private debt }\end{array}$ & & & $\begin{array}{c}0.003^{* * * *} \\
(0.001)\end{array}$ \\
\hline Concessional debt & $\begin{array}{c}-0.033^{* * *} \\
(0.009)\end{array}$ & & \\
\hline Funding ratio & & $\begin{array}{l}0.002 * \\
(0.001)\end{array}$ & \\
\hline Currency overvaluation & & & $\begin{array}{c}0.165^{* * *} \\
(0.015)\end{array}$ \\
\hline Currency mismatch & & & $\begin{array}{c}0.014 \\
(0.033)\end{array}$ \\
\hline FDI & & & $\begin{array}{c}-0.101^{* *} \\
(0.046)\end{array}$ \\
\hline Constant & $\begin{array}{c}-2.678^{* * *} \\
(0.616)\end{array}$ & $\begin{array}{c}-4.161 * * * \\
(0.371)\end{array}$ & $\begin{array}{c}-3.617^{* * * *} \\
(0.395)\end{array}$ \\
\hline No. of observations & 3,089 & 2,797 & 2,395 \\
\hline No. of countries & 106 & 106 & 99 \\
\hline
\end{tabular}

Note: $* * *, * *, *$ denote statistical significance at the 1 percent, 5 percent, 10 percent level respectively. Standard errors are in parentheses. 
Table 7. Probability of crises

Dependent variable: Crisis indicator $(1=$ crisis, $0=$ no crisis $)$

\begin{tabular}{|c|c|c|c|c|c|}
\hline & \multirow[b]{2}{*}{ Points of interest } & \multicolumn{3}{|c|}{ Probabilities } & \multirow[b]{2}{*}{ Reference } \\
\hline & & Debt crisis & Banking crisis & Currency crisis & \\
\hline $\begin{array}{l}\text { Change in U.S. real } \\
\text { interest rate }\end{array}$ & $\begin{array}{l}2 \text { percentage points vs. } \\
\text { unchanged }\end{array}$ & & & $\begin{array}{l}6.0 \text { percent vs. } \\
4.1 \text { percent }\end{array}$ & $\begin{array}{l}\text { Cumulative increase in U.S. Fed Funds rate from end- } 2015 \\
\text { to mid- } 2018 \text { vs. no change in interest rate }\end{array}$ \\
\hline GDP growth & -1 percent vs. 4 percent & $\begin{array}{l}1.9 \text { percent vs. } \\
1.2 \text { percent }\end{array}$ & & & Average EMDE growth during crisis vs. non-crisis episodes \\
\hline Short-term debt & $\begin{array}{l}30 \text { percent vs. } 10 \\
\text { percent }\end{array}$ & $\begin{array}{l}2.0 \text { percent vs. } \\
1.2 \text { percent }\end{array}$ & & & Mexico's 1982 episode vs. EMDE non-crisis episodes \\
\hline Debt service & $\begin{array}{l}50 \text { percent vs. } 15 \\
\text { percent }\end{array}$ & $\begin{array}{l}2.8 \text { percent vs. } \\
1.1 \text { percent }\end{array}$ & $\begin{array}{l}5.5 \text { percent vs. } \\
2.1 \text { percent }\end{array}$ & & Mexico’s 1982 episode vs. EMDE non-crisis episodes \\
\hline Reserves cover & 1 month vs. 4 months & $\begin{array}{l}3.1 \text { percent vs. } \\
0.6 \text { percent }\end{array}$ & $\begin{array}{l}3.3 \text { percent vs. } \\
2.0 \text { percent }\end{array}$ & $\begin{array}{l}5.0 \text { percent vs. } \\
3.8 \text { percent }\end{array}$ & Mexico's 1982 episode vs. EMDE non-crisis episodes \\
\hline $\begin{array}{l}\text { Change in government } \\
\text { debt }\end{array}$ & $\begin{array}{l}30 \text { percentage points of } \\
\text { GDP vs. unchanged }\end{array}$ & $\begin{array}{l}2.0 \text { percent vs. } \\
1.4 \text { percent }\end{array}$ & & $\begin{array}{l}6.6 \text { percent vs. } \\
4.1 \text { percent }\end{array}$ & $\begin{array}{l}\text { Median government debt accumulation episode vs. no } \\
\text { accumulation }\end{array}$ \\
\hline Change in private debt & $\begin{array}{l}15 \text { percentage points of } \\
\text { GDP vs. unchanged }\end{array}$ & & $\begin{array}{l}4.8 \text { percent vs. } \\
2.2 \text { percent }\end{array}$ & $\begin{array}{l}7.5 \text { percent vs. } \\
3.9 \text { percent }\end{array}$ & $\begin{array}{l}\text { Median private debt accumulation episode vs no } \\
\text { accumulation }\end{array}$ \\
\hline Concessional debt & $\begin{array}{l}50 \text { percent vs. } 25 \\
\text { percent }\end{array}$ & $\begin{array}{l}0.8 \text { percent vs. } \\
1.6 \text { percent }\end{array}$ & & & Average EMDE crisis vs. non-crisis episodes \\
\hline Funding ratio & $\begin{array}{l}200 \text { percent vs. } 90 \\
\text { percent }\end{array}$ & & $\begin{array}{l}3.0 \text { percent vs. } \\
2.3 \text { percent }\end{array}$ & & Ukraine's 2008-09 share vs. EMDE non-crisis episodes \\
\hline Currency overvaluation & $\begin{array}{l}15 \text { percent vs. } 0 \\
\text { percent }\end{array}$ & & & $\begin{array}{l}19.5 \text { percent vs. } \\
2.2 \text { percent }\end{array}$ & Thailand's real appreciation $1994-97$ vs. no appreciation. \\
\hline
\end{tabular}

Note: The table shows the predicted probability of crises in the following year evaluated at various points of interest for each explanatory variable (with the other variables held at their average values). These probabilities are included for variables that are statistically significant at the 10 percent level or below in the baseline regressions. 
Table 8. Logit and probit models for twin crisis

Dependent variable: Crisis indicator $(1=$ crisis, $0=$ no crisis $)$

\begin{tabular}{lccc}
\hline & $\begin{array}{c}\text { Random effects } \\
\text { Logit }\end{array}$ & $\begin{array}{c}\text { Random effects } \\
\text { Probit }\end{array}$ & $\begin{array}{c}\text { Fixed effects } \\
\text { Logit }\end{array}$ \\
\hline \hline Change in U.S. real interest rate & 0.158 & 0.068 & 0.096 \\
& $(0.177)$ & $(0.073)$ & $(0.184)$ \\
GDP growth & $-0.075^{* *}$ & $-0.035^{* *}$ & $-0.146^{* * *}$ \\
& $(0.030)$ & $(0.014)$ & $(0.049)$ \\
Short-term debt & $0.056^{* * *}$ & $0.022^{* * *}$ & $0.073^{* * *}$ \\
& $(0.015)$ & $(0.007)$ & $(0.026)$ \\
Debt service & $0.038^{* * *}$ & $0.015^{* * *}$ & 0.026 \\
& $(0.012)$ & $(0.005)$ & $(0.017)$ \\
Reserves cover & $-0.277^{* *}$ & $-0.107^{* *}$ & $-0.391^{* *}$ \\
& $(0.120)$ & $(0.046)$ & $(0.188)$ \\
Change in government debt & $0.016^{*}$ & 0.007 & $0.018^{* *}$ \\
& $(0.009)$ & $(0.005)$ & $(0.010)$ \\
Change in private debt & $0.088^{* * *}$ & $0.040^{* * *}$ & $0.161^{* * *}$ \\
& $(0.031)$ & $(0.015)$ & $(0.060)$ \\
Change in government debt & -0.001 & 0.000 & -0.004 \\
$\quad$ x Change in private debt & $(0.001)$ & $(0.001)$ & $(0.005)$ \\
Constant & $-5.639^{* * *}$ & $-2.716^{* * *}$ & \\
\hline No. of observations & -0.584 & -0.228 & \\
No. of countries & 2,908 & 2,908 & 696 \\
\hline & 107 & 107 & 21 \\
\hline
\end{tabular}

Note: $* * *, * *, *$ denote statistical significance at the 1 percent, 5 percent, 10 percent level respectively. Standard errors are in parentheses. 
Table 9. Random effects probit model

Dependent variable: Crisis indicator $(1=$ crisis, $0=$ no crisis $)$

\begin{tabular}{|c|c|c|c|}
\hline & Debt crisis & Banking crisis & Currency crisis \\
\hline Change in U.S. real interest rate & $\begin{array}{l}-0.027 \\
(0.057)\end{array}$ & $\begin{array}{c}0.007 \\
(0.046)\end{array}$ & $\begin{array}{l}0.118^{* *} \\
(0.048)\end{array}$ \\
\hline GDP growth & $\begin{array}{c}-0.044 * * * \\
(0.012)\end{array}$ & $\begin{array}{l}-0.011 \\
(0.011)\end{array}$ & $\begin{array}{l}-0.006 \\
(0.010)\end{array}$ \\
\hline Short-term debt & $\begin{array}{c}0.010 \\
(0.006)\end{array}$ & $\begin{array}{c}0.005 \\
(0.005)\end{array}$ & $\begin{array}{c}0.002 \\
(0.005)\end{array}$ \\
\hline Debt service & $\begin{array}{c}0.012 * * * \\
(0.004)\end{array}$ & $\begin{array}{c}0.013^{* * *} \\
(0.003)\end{array}$ & $\begin{array}{c}0.004 \\
(0.004)\end{array}$ \\
\hline Reserves cover & $\begin{array}{c}-0.215^{* * *} \\
(0.045)\end{array}$ & $\begin{array}{c}-0.063^{* * *} \\
(0.025)\end{array}$ & $\begin{array}{c}-0.060^{* *} \\
(0.028)\end{array}$ \\
\hline Change in government debt & $\begin{array}{l}0.007^{*} \\
(0.004)\end{array}$ & & $\begin{array}{l}0.008^{*} \\
(0.004)\end{array}$ \\
\hline Change in private debt & & $\begin{array}{l}0.021^{* *} \\
(0.010)\end{array}$ & $\begin{array}{l}0.024^{*} \\
(0.013)\end{array}$ \\
\hline $\begin{array}{l}\text { Change in government debt } \\
\mathrm{x} \text { Change in private debt }\end{array}$ & & & $\begin{array}{l}0.001^{* * *} \\
0.000\end{array}$ \\
\hline Concessional debt & $\begin{array}{c}-0.014^{* * *} \\
(0.004)\end{array}$ & & \\
\hline Funding ratio & & $\begin{array}{l}0.001 * \\
(0.001)\end{array}$ & \\
\hline Currency overvaluation & & & $\begin{array}{c}0.079 * * * \\
(0.007)\end{array}$ \\
\hline Currency mismatch & & & $\begin{array}{c}0.004 \\
(0.016)\end{array}$ \\
\hline FDI & & & $\begin{array}{c}-0.047^{* *} \\
(0.020)\end{array}$ \\
\hline Constant & $\begin{array}{c}-1.537^{* * *} \\
(0.264)\end{array}$ & $\begin{array}{c}-2.186^{* * *} \\
(0.157)\end{array}$ & $\begin{array}{c}-1.861^{* * *} \\
(0.182)\end{array}$ \\
\hline No. of observations & 3,089 & 2,797 & 2,395 \\
\hline No. of countries & 106 & 106 & 99 \\
\hline
\end{tabular}

Note: ${ }^{* *}, * *, *$ denote statistical significance at the 1 percent, 5 percent, 10 percent level respectively. Standard errors are in parentheses. 
Table 10. Fixed effects logit model

Dependent variable: Crisis indicator $(1=$ crisis, $0=$ no crisis $)$

\begin{tabular}{|c|c|c|c|}
\hline & Debt crisis & Banking crisis & Currency crisis \\
\hline Change in U.S. real interest rate & $\begin{array}{l}-0.121 \\
(0.130)\end{array}$ & $\begin{array}{l}-0.021 \\
(0.106)\end{array}$ & $\begin{array}{l}0.257^{* *} \\
(0.104)\end{array}$ \\
\hline GDP growth & $\begin{array}{c}-0.095^{* * *} \\
(0.034)\end{array}$ & $\begin{array}{l}-0.013 \\
(0.026)\end{array}$ & $\begin{array}{l}-0.008 \\
(0.022)\end{array}$ \\
\hline Short-term debt & $\begin{array}{c}0.056^{* * * *} \\
(0.020)\end{array}$ & $\begin{array}{c}0.012 \\
(0.017)\end{array}$ & $\begin{array}{l}-0.015 \\
(0.016)\end{array}$ \\
\hline Debt service & $\begin{array}{c}0.032 * * \\
(0.015)\end{array}$ & $\begin{array}{c}0.026 * * * \\
(0.010)\end{array}$ & $\begin{array}{c}0.001 \\
(0.011)\end{array}$ \\
\hline Reserves cover & $\begin{array}{c}-0.586^{* * *} \\
(0.154)\end{array}$ & $\begin{array}{c}-0.256^{* * *} \\
(0.082)\end{array}$ & $\begin{array}{c}-0.219^{* * *} \\
(0.085)\end{array}$ \\
\hline Change in government debt & $\begin{array}{l}0.018^{*} \\
(0.010)\end{array}$ & & $\begin{array}{c}0.013^{* *} \\
(0.007)\end{array}$ \\
\hline Change in private debt & & $\begin{array}{l}0.055^{* *} \\
(0.027)\end{array}$ & $\begin{array}{l}0.067 * * \\
(0.029)\end{array}$ \\
\hline $\begin{array}{l}\text { Change in government debt } \\
\mathrm{x} \text { Change in private debt }\end{array}$ & & & $\begin{array}{c}0.003 * * * \\
(0.001)\end{array}$ \\
\hline Concessional debt & $\begin{array}{c}-0.059^{* *} \\
(0.023)\end{array}$ & & \\
\hline Funding ratio & & $\begin{array}{l}-0.001 \\
(0.003)\end{array}$ & \\
\hline Currency overvaluation & & & $\begin{array}{c}0.131 * * * \\
(0.016)\end{array}$ \\
\hline Currency mismatch & & & $\begin{array}{c}0.037 \\
(0.049)\end{array}$ \\
\hline FDI & & & $\begin{array}{l}-0.087 \\
(0.059)\end{array}$ \\
\hline No. of observations & 1,186 & 1,705 & 1,688 \\
\hline No. of countries & 35 & 55 & 63 \\
\hline
\end{tabular}

Note: $* * *, * *, *$ denote statistical significance at the 1 percent, 5 percent, 10 percent level respectively. Standard errors are in parentheses. 
Appendix 1. Episodes of rapid accumulation of government debt

\begin{tabular}{|c|c|c|c|c|c|}
\hline Albania & $2007-2015$ & & & & \\
\hline Algeria & $1970-1978$ & $1982-1988^{12}$ & $1992-1995^{2}$ & $\underline{2013-2018}$ & \\
\hline Angola & 1997-1999 & $\underline{2012-2018}^{2}$ & & & \\
\hline Argentina & $1968-1975^{2}$ & $1980-1989^{123}$ & $1992-2002^{123}$ & $\underline{2011-2018}^{23}$ & \\
\hline Aruba & $2000-2002$ & $\underline{2008-2018}$ & & & \\
\hline Azerbaijan & $1994-1999^{1}$ & $2008-2018^{2}$ & & & \\
\hline Bangladesh & $1973-1977^{2}$ & $1980-1987^{1}$ & 1989-1994 & $1997-2002$ & \\
\hline Belarus & $2005-2011^{2}$ & $2013-2016^{2}$ & & & \\
\hline Benin & 1972-1983 & $1992-1994^{2}$ & $2006-2011$ & $\underline{2013-2018}$ & \\
\hline Bolivia & $1970-1985^{123}$ & $2001-2004$ & & & \\
\hline Bosnia \& Herzegovina & 2007-2014 & & & & \\
\hline Brazil & $1967-1987^{23}$ & $1989-1992^{12}$ & $1995-2002^{2}$ & $\underline{2013-2018}^{2}$ & \\
\hline Bulgaria & $1981-1993^{3}$ & & & & \\
\hline Burkina Faso & $1970-1987$ & $1989-1994^{12}$ & $\underline{2006-2018}$ & & \\
\hline Burundi & $1971-1999^{1}$ & 2001-2004 & & & \\
\hline Cambodia & $1995-2003$ & & & & \\
\hline Cameroon & $1970-1979$ & $1984-1995^{123}$ & 2008-2018 & & \\
\hline Central African Rep. & $1970-1974^{1}$ & 1979-1984 & $1990-1994^{12}$ & 1999-2005 & 2009-2014 \\
\hline Chad & 1972-1979 & $1986-1994^{12}$ & $1998-2000$ & $\underline{2008-2018}$ & \\
\hline Chile & $1962-1970$ & $1972-1975^{12}$ & $1981-1986^{123}$ & 2007-2018 & \\
\hline China & $1997-2003^{1}$ & 2006-2009 & $\underline{2011-2018}$ & & \\
\hline Colombia & 1960-1972 & $1978-1986^{12}$ & $1995-2002^{1}$ & $\underline{2008-2018}$ & \\
\hline Congo, Dem. Rep. & $1970-1976^{23}$ & $1979-1983^{12}$ & $1993-1998^{12}$ & & \\
\hline Congo, Rep. & $1973-1985^{3}$ & $1992-1994^{12}$ & $2011-2016$ & & \\
\hline Costa Rica & $1958-1973$ & $1975-1978$ & $1988-2002^{12}$ & 2008-2018 & \\
\hline Cote d'Ivoire & $1970-1994^{123}$ & & & & \\
\hline Croatia & $1998-2005^{1}$ & $2007-2014$ & & & \\
\hline Dominican Republic & $1997-2003^{123}$ & $2007-2013$ & & & \\
\hline Ecuador & $1997-1999^{123}$ & $\underline{2011-2018}$ & & & \\
\hline Egypt, Arab Rep. & $1970-1982^{123}$ & $1989-1992^{2}$ & $2000-2005$ & $2008-2018^{2}$ & \\
\hline El Salvador & $1977-1985^{2}$ & $\underline{1998-2018}$ & & & \\
\hline Eritrea & 1995-2003 & & & & \\
\hline Ethiopia & $1974-1994^{2}$ & & & & \\
\hline
\end{tabular}


Appendix 1. Episodes of rapid accumulation of government debt (continued)

\begin{tabular}{|c|c|c|c|c|c|}
\hline Georgia & $2007-2010$ & $\underline{2013-2018}$ & & & \\
\hline Ghana & $1982-1987^{12}$ & $1990-1994^{2}$ & $1998-2000^{2}$ & $2006-2018^{2}$ & \\
\hline Guatemala & 1954-1972 & $1975-1985^{2}$ & $2008-2013$ & & \\
\hline Guinea & $1992-1999^{1}$ & $2003-2005^{2}$ & & & \\
\hline Haiti & 1973-1983 & $1985-1992^{12}$ & 2011-2016 & & \\
\hline Honduras & $1950-1986^{3}$ & & & & \\
\hline Hungary & $1989-1993^{1}$ & $2001-2011^{1}$ & & & \\
\hline India & $1974-1992^{1}$ & $1996-2003$ & & & \\
\hline Indonesia & $1980-1987$ & $1997-2000^{123}$ & & & \\
\hline Iran, Islamic Rep. & 1974-1981 & $1985-1988^{2}$ & $2011-2016^{2}$ & & \\
\hline Jordan & $1969-1990^{123}$ & $\underline{2008-2018}$ & & & \\
\hline Kazakhstan & $1996-1999^{2}$ & $2007-2015^{12}$ & & & \\
\hline Kenya & $1963-1982$ & $1984-1987^{1}$ & $1989-1993^{12}$ & $\underline{2007-2018}$ & \\
\hline Kuwait & 1987-1991 & $\underline{2013-2018}$ & & & \\
\hline Kyrgyz Republic & $1994-2000^{12}$ & $2013-2015$ & & & \\
\hline Lao PDR & $1976-1982^{2}$ & $1985-1988^{2}$ & $1996-1998^{2}$ & & \\
\hline Lebanon & $1972-1983^{2}$ & $1987-1990^{12}$ & 1993-2006 & $\underline{2012-2018}$ & \\
\hline Libya & 1977-1990 & $\underline{2008-2017}$ & & & \\
\hline Madagascar & $1976-1988^{123}$ & & & & \\
\hline Malawi & $1975-1987^{3}$ & $1991-1994^{2}$ & 1997-2002 & & \\
\hline Malaysia & 1955-1972 & 1974-1977 & $1980-1987$ & $2007-2015$ & \\
\hline Mali & $1973-1985^{1}$ & $1990-1994^{2}$ & & & \\
\hline Mauritania & $1970-1987^{1}$ & $1992-2000^{2}$ & $\underline{2013-2018}$ & & \\
\hline Mexico & $1971-1977^{2}$ & $1980-1987^{123}$ & $1993-1995^{12}$ & $2007-2016$ & \\
\hline Moldova & $2008-2015^{1}$ & & & & \\
\hline Mongolia & $1992-1999^{2}$ & 2010-2017 & & & \\
\hline Morocco & $1974-1985^{123}$ & $\underline{2008-2018}$ & & & \\
\hline Mozambique & $2007-2016^{2}$ & & & & \\
\hline Nepal & $1970-1994^{12}$ & 1997-1999 & & & \\
\hline Niger & 1970-1974 & $1977-1985^{13}$ & $1989-1994^{2}$ & $1996-2000$ & 2013-2018 \\
\hline Nigeria & $1975-1991^{123}$ & $\underline{2008-2018}^{12}$ & & & \\
\hline North Macedonia & $2008-2016$ & & & & \\
\hline Oman & 1990-1994 & 2008-2018 & & & \\
\hline
\end{tabular}


Appendix 1. Episodes of rapid accumulation of government debt (continued)

\begin{tabular}{|c|c|c|c|c|c|}
\hline Pakistan & $1962-1972^{2}$ & 1981-2001 & $2007-2013$ & $\underline{2015-2018}$ & \\
\hline Panama & $1975-1983^{3}$ & $1985-1990^{1}$ & & & \\
\hline Papua New Guinea & 1970-1976 & $1978-2001^{2}$ & 2011-2016 & & \\
\hline Paraguay & $1981-1987^{23}$ & $1996-2002^{2}$ & $\underline{2011-2018}$ & & \\
\hline Peru & 2001-2003 & $\underline{2013-2018}$ & & & \\
\hline Philippines & 1963-1972 & $1974-1987^{123}$ & $1998-2003^{2}$ & & \\
\hline Poland & $1990-1994^{1}$ & $2000-2013$ & & & \\
\hline Romania & $1995-2000^{12}$ & $2007-2014$ & & & \\
\hline Russian Federation & 1996-1999 ${ }^{123}$ & & & & \\
\hline Rwanda & $1975-1995^{2}$ & $1998-2002$ & & & \\
\hline Saudi Arabia & 1989-1999 & $\underline{2014-2018}$ & & & \\
\hline Senegal & $1972-1985^{3}$ & $1992-1994^{2}$ & $\underline{1999-2018}$ & & \\
\hline Sierra Leone & $1970-1994^{123}$ & 2013-2018 & & & \\
\hline South Africa & 1964-1972 & 1974-1978 & 1990-1995 & $\underline{2008-2018}^{2}$ & \\
\hline Sri Lanka & $1970-1982^{2}$ & $1984-1989^{1}$ & 1997-2002 & $\underline{2012-2018}$ & \\
\hline Sudan & $2007-2012^{2}$ & $\underline{2015-2018}$ & & & \\
\hline Syrian Arab Republic & $1975-1989^{2}$ & & & & \\
\hline Tajikistan & $\underline{2014-2018}^{2}$ & & & & \\
\hline Tanzania & $1970-1980$ & $1982-1993^{123}$ & $\underline{2008-2018}$ & & \\
\hline Thailand & 1963-1972 & $1975-1986^{1}$ & $1996-2000^{12}$ & & \\
\hline Togo & $1972-1985^{3}$ & $1990-1994^{12}$ & $1997-2000$ & 2004-2007 & $2010-2016$ \\
\hline Tunisia & $1975-1978$ & $1980-1997^{1}$ & $\underline{2010-2018}$ & & \\
\hline Turkey & $1958-1970$ & $1974-1985^{123}$ & $1990-1994^{2}$ & $1998-2001^{12}$ & \\
\hline Uganda & $\underline{2009-2018}$ & & & & \\
\hline Ukraine & $1995-1999^{123}$ & $2007-2016^{123}$ & & & \\
\hline United Arab Emirates & 1973-1979 & 1981-1988 & $1990-1993$ & 2001-2009 & \\
\hline Uruguay & $1970-1976^{2}$ & $1979-1984^{123}$ & $1996-2003^{123}$ & & \\
\hline Uzbekistan & $1997-2001^{2}$ & $\underline{2014-2018}^{2}$ & & & \\
\hline Venezuela, RB & 1964-1972 & $1975-1994^{123}$ & $2000-2003^{2}$ & $2008-2013^{2}$ & \\
\hline Vietnam & $2005-2016$ & & & & \\
\hline West Bank \& Gaza & $2000-2005$ & $2010-2015$ & & & \\
\hline Yemen, Rep. & $1994-1996^{12}$ & $\underline{2008-2018}$ & & & \\
\hline Zambia & $1970-1982^{23}$ & $1987-1991^{2}$ & $1997-2000$ & & \\
\hline Zimbabwe & $1975-1987^{2}$ & $1989-1998^{12}$ & $2001-2009^{2}$ & $2012-2016$ & \\
\hline
\end{tabular}

Note: Superscripts 1, 2, and 3 mean that rapid accumulation episodes are associated with banking, currency, and debt crises, respectively. Underlined years indicate episodes that are still underway. 
Appendix 2. Episodes of rapid accumulation of private debt

\begin{tabular}{|c|c|c|c|c|}
\hline Algeria & 1997-2002 & 2004-2009 & 2011-2018 & \\
\hline Angola & 2000-2009 & & & \\
\hline Argentina & $1965-1974^{2}$ & $1976-1982^{123}$ & $1985-1989^{12}$ & $1991-2002^{123} \underline{2014-2018}^{23}$ \\
\hline Armenia & $\underline{2003-2018}$ & & & \\
\hline Aruba & 1986-1990 & 1993-1996 & $1998-2003$ & $\underline{2008-2017}$ \\
\hline Azerbaijan & 1996-2009 & $2011-2015^{2}$ & & \\
\hline Bangladesh & $1974-1990^{12}$ & $\underline{1992-2018}$ & & \\
\hline Belarus & $1994-1998^{12}$ & $2001-2010^{2}$ & & \\
\hline Benin & 1966-1975 & 1981-1983 & $2002-2016$ & \\
\hline Bolivia & $1986-1999^{1}$ & $\underline{2008-2018}$ & & \\
\hline Bosnia \& Herzegovina & $2001-2008$ & $\underline{2016-2018}$ & & \\
\hline Brazil & $2004-2015^{2}$ & & & \\
\hline Bulgaria & $1994-2009^{12}$ & & & \\
\hline Burkina Faso & 1960-1978 & $1984-1990^{1}$ & 1995-1997 & 2011-2018 \\
\hline Burundi & 1969-1981 & $1985-1994^{1}$ & 1997-2002 & $2008-2011$ \\
\hline Cameroon & $1997-2016$ & & & \\
\hline Central African Rep. & $1994-2004^{12}$ & $2006-2013$ & & \\
\hline Chad & $\underline{2006-2018}$ & & & \\
\hline Chile & $1980-1984^{123}$ & $1988-2002$ & $2006-2015$ & \\
\hline China & 1980-1993 & $1995-2003^{1}$ & $\underline{2008-2018}$ & \\
\hline Colombia & $1990-1998^{1}$ & $2005-2015$ & & \\
\hline Congo, Rep. & 1996-1999 & 2006-2016 & & \\
\hline Costa Rica & $1991-2008^{12}$ & $\underline{2010-2018}$ & & \\
\hline Croatia & 2000-2012 & & & \\
\hline Dominican Republic & $1985-1987^{2}$ & $1991-2002^{123}$ & $\underline{2006-2018}$ & \\
\hline Ecuador & $1974-1978$ & $1980-1984^{123}$ & $1989-2000^{123}$ & $\underline{2003-2018}^{3}$ \\
\hline Egypt, Arab Rep. & $1973-1986^{123}$ & $1992-2001$ & $2014-2016^{2}$ & \\
\hline El Salvador & $1990-2000$ & $2002-2007$ & $\underline{2012-2018}$ & \\
\hline Eritrea & $\underline{2011-2015}$ & & & \\
\hline Ethiopia & $1962-1978$ & $1991-1999^{2}$ & 2004-2006 & \\
\hline Ghana & $1967-1971$ & $1981-1989^{12}$ & $1991-2008^{2}$ & $2011-2015^{2}$ \\
\hline Guatemala & $1973-1984^{2}$ & 1991-2006 & $2011-2015$ & \\
\hline Guinea & $1991-1995^{1}$ & $1999-2006^{2}$ & 2009-2015 & \\
\hline
\end{tabular}


Appendix 2. Episodes of rapid accumulation of private debt (continued)

\begin{tabular}{|c|c|c|c|c|c|}
\hline Haiti & $1992-2002^{12}$ & 2007-2014 & & & \\
\hline Honduras & $1950-1978$ & $1981-1987^{3}$ & $1995-2007$ & $\underline{2011-2018}$ & \\
\hline Hungary & $1969-1987$ & $1995-2009^{1}$ & & & \\
\hline India & $1967-1989$ & 1994-2013 & & & \\
\hline Indonesia & $1980-1990$ & $1993-1997^{123}$ & $2009-2015$ & & \\
\hline Iran, Islamic Rep. & $1955-1970$ & 1974-1980 & $1984-1986^{2}$ & $\underline{1996-2016}^{2}$ & \\
\hline Jordan & $1972-1989^{123}$ & $1992-2001$ & 2003-2006 & & \\
\hline Kazakhstan & $1997-2007^{12}$ & & & & \\
\hline Kenya & $1966-1980$ & $1987-2004^{12}$ & $2006-2015$ & & \\
\hline Kosovo & 2001-2011 & $\underline{2013-2018}$ & & & \\
\hline Kuwait & $1971-1990^{1}$ & 1993-1998 & 2006-2009 & $2012-2016$ & \\
\hline Kyrgyz Republic & $1997-2008^{2}$ & $\underline{2011-2018}$ & & & \\
\hline Lao PDR & $1989-1998^{2}$ & 2006-2010 & & & \\
\hline Lebanon & $1970-1982^{2}$ & $1993-2000$ & 2005-2017 & & \\
\hline Liberia & $1988-1996^{1}$ & $\underline{2000-2016}$ & & & \\
\hline Libya & 1980-1988 & 1991-1995 & $2007-2015$ & & \\
\hline Madagascar & $1975-1980^{3}$ & $1983-1986^{12}$ & 1989-1991 & $2002-2015^{2}$ & \\
\hline Malawi & $1965-1971$ & 1973-1979 & $1988-1992^{2}$ & $1997-2012^{2}$ & \\
\hline Malaysia & $1955-1986$ & 1988-1991 & $1993-1997^{12}$ & $2008-2016$ & \\
\hline Mali & 1966-1976 & $1994-1999^{2}$ & 2001-2004 & $\underline{2008-2018}$ & \\
\hline Mauritania & 2006-2009 & & & & \\
\hline Mexico & 1983-1986 & $1988-1995^{12}$ & 2010-2016 & & \\
\hline Moldova & $1994-2007^{23}$ & & & & \\
\hline Mongolia & $1997-2007^{12}$ & 2010-2013 & & & \\
\hline Morocco & $1990-2000$ & 2003-2012 & & & \\
\hline Mozambique & $1996-2000$ & $2004-2015^{2}$ & & & \\
\hline Myanmar & $1965-1972$ & $1974-1978^{2}$ & $1989-1992^{2}$ & $1994-2001^{2}$ & $\underline{2008-2018}^{2}$ \\
\hline Nepal & $1963-1981$ & $1983-2009^{12}$ & 2011-2018 & & \\
\hline Nicaragua & $1975-1982^{23}$ & $1996-2007^{1}$ & 2011-2018 & & \\
\hline Niger & $1971-1975$ & $1977-1981^{13}$ & 2006-2018 & & \\
\hline Nigeria & $1970-1980$ & $1990-1992^{1}$ & $1996-2001^{2}$ & $2006-2009^{1}$ & \\
\hline North Macedonia & $2001-2015$ & & & & \\
\hline Oman & $1972-1978$ & 1981-1988 & 1990-1998 & 2005-2009 & $\underline{2011-2017}$ \\
\hline
\end{tabular}


Appendix 2. Episodes of rapid accumulation of private debt (continued)

\begin{tabular}{|c|c|c|c|c|c|}
\hline Pakistan & $1957-1972^{2}$ & $1975-1979$ & 1984-1986 & $1991-2000$ & $2002-2008$ \\
\hline Panama & 1990-2001 & $\underline{2013-2018}$ & & & \\
\hline Papua New Guinea & $1978-1987$ & 1996-1998 & 2004-2013 & & \\
\hline Paraguay & 1961-1971 & $1987-1997^{12}$ & $2006-2015$ & & \\
\hline Peru & $1969-1973$ & $1978-1983^{123}$ & 1989-1999 & $2006-2015$ & \\
\hline Philippines & $1971-1983^{123}$ & $1986-1997^{12}$ & $\underline{2006-2018}$ & & \\
\hline Poland & $1995-2002$ & 2004-2016 & & & \\
\hline Romania & 2000-2011 & & & & \\
\hline Russian Federation & $1996-2015^{123}$ & & & & \\
\hline Rwanda & $1968-1978$ & $1983-1988$ & $1991-1994^{2}$ & $1996-2015$ & \\
\hline Saudi Arabia & 1973-1988 & 1990-1998 & 2000-2009 & 2012-2016 & \\
\hline Senegal & $1967-1979^{3}$ & $\underline{1995-2018}$ & & & \\
\hline Serbia & $2002-2010$ & & & & \\
\hline Sierra Leone & $1971-1978^{3}$ & 1999-2009 & & & \\
\hline South Africa & $1967-1973$ & $1980-1985^{23}$ & $1993-2008$ & & \\
\hline Sri Lanka & $1973-1979^{2}$ & 1991-1995 & $\underline{2009-2017}$ & & \\
\hline Sudan & $1974-1980^{23}$ & $1999-2012^{2}$ & & & \\
\hline Syrian Arab Republic & $1980-1984$ & $1988-1995^{2}$ & $\underline{2002-2010}$ & & \\
\hline Tajikistan & 2004-2008 & $2010-2015^{2}$ & & & \\
\hline Tanzania & 2000-2008 & $2013-2015$ & & & \\
\hline Thailand & $1950-1997^{12}$ & $2007-2015$ & & & \\
\hline Togo & $1965-1980^{3}$ & 1985-1987 & $1990-1993^{12}$ & $2002-2016$ & \\
\hline Tunisia & $1980-1986$ & $1988-2002^{1}$ & $\underline{2006-2017}$ & & \\
\hline Turkey & $1989-1997^{2}$ & $\underline{2003-2018}^{2}$ & & & \\
\hline Uganda & $1979-1981^{23}$ & $1987-2015^{12}$ & & & \\
\hline Ukraine & $1996-2009^{123}$ & & & & \\
\hline United Arab Emirates & $1973-1978$ & $1980-1988$ & 1990-1998 & $2000-2009$ & $2013-2016$ \\
\hline Uruguay & $1974-1982^{123}$ & $1994-2002^{123}$ & & & \\
\hline Venezuela, RB & $1963-1978$ & $\underline{2003-2013}^{2}$ & & & \\
\hline Vietnam & $1992-2010^{1}$ & $\underline{2012-2018}$ & & & \\
\hline West Bank \& Gaza & 1998-2006 & $\underline{2008-2016}$ & & & \\
\hline Yemen, Rep. & $1996-2007^{1}$ & & & & \\
\hline Zambia & $1965-1974$ & $1978-1982^{23}$ & $1992-1996^{12}$ & $2002-2008^{2}$ & $2010-2015^{2}$ \\
\hline Zimbabwe & $1982-1989^{2}$ & $1994-1997^{12}$ & $1999-2002^{2}$ & & \\
\hline
\end{tabular}

Note: Superscripts 1, 2, and 3 mean that rapid accumulation episodes are associated with banking, currency, and debt crises, respectively.Underlines indicate episodes that are still underway. 
Appendix 3. List of financial crises

\begin{tabular}{|c|c|c|c|}
\hline & Banking crisis & Currency crisis & Debt crisis \\
\hline Albania & 1994 & 1997 & 1990 \\
\hline Algeria & 1990 & $1988 ; 1994$ & \\
\hline Angola & & $1991 ; 1996 ; 2015 ; 2018$ & 1988 \\
\hline Argentina & 1980; 1989; 1995; 2001 & $1975 ; 1981 ; 1987 ; 2002 ; 2013 ; 2018$ & $1982 ; 2001 ; 2014$ \\
\hline Armenia & 1994 & & \\
\hline Azerbaijan & 1995 & 2015 & \\
\hline Bangladesh & 1987 & 1976 & \\
\hline Belarus & 1995 & 1997; 2009; 2015 & \\
\hline Belize & & & $2007 ; 2012 ; 2017$ \\
\hline Benin & 1988 & 1994 & \\
\hline Bolivia & 1986; 1994 & $1973 ; 1981$ & 1980 \\
\hline Bosnia \& Herzegovina & 1992 & & \\
\hline Botswana & & 1984 & \\
\hline Brazil & 1990; 1994 & 1976; 1982; 1987; 1992; 1999; 2015 & 1983 \\
\hline Bulgaria & 1996 & 1996 & 1990 \\
\hline Burkina Faso & 1990 & 1994 & \\
\hline Burundi & 1994 & & \\
\hline Cabo Verde & 1993 & & \\
\hline Cambodia & & $1971 ; 1992$ & \\
\hline Cameroon & $1987 ; 1995$ & 1994 & 1989 \\
\hline Central African Rep. & $1976 ; 1995$ & 1994 & \\
\hline Chad & $1983 ; 1992$ & 1994 & \\
\hline Chile & 1976; 1981 & $1972 ; 1982$ & 1983 \\
\hline China & 1998 & & \\
\hline Colombia & 1982; 1998 & 1985 & \\
\hline Comoros & & 1994 & \\
\hline Congo, Dem. Rep. & $1983 ; 1991 ; 1994$ & $\begin{array}{l}\text { 1976; 1983; 1989; 1994; 1999; 2009; } \\
2016\end{array}$ & 1976 \\
\hline Congo, Rep. & 1992 & 1994 & 1986 \\
\hline Costa Rica & 1987; 1994 & $1981 ; 1991$ & 1981 \\
\hline Cote d'Ivoire & 1988 & 1994 & $1984 ; 2001 ; 2010$ \\
\hline Croatia & 1998 & & \\
\hline Djibouti & 1991 & & \\
\hline Dominica & & & 2002 \\
\hline Dominican Republic & 2003 & $1985 ; 1990 ; 2003$ & $1982 ; 2003$ \\
\hline Ecuador & $1982 ; 1998$ & $1982 ; 1999$ & $1982 ; 1999 ; 2008$ \\
\hline Egypt, Arab Rep. & 1980 & 1979; 1990; 2016 & 1984 \\
\hline El Salvador & 1989 & 1986 & \\
\hline Equatorial Guinea & 1983 & $1980 ; 1994$ & \\
\hline Eritrea & 1993 & & \\
\hline Eswatini & 1995 & $1985 ; 2015$ & \\
\hline Ethiopia & & 1993 & \\
\hline Fiji & & 1998 & \\
\hline
\end{tabular}


Appendix 3. List of financial crises (continued)

\begin{tabular}{|c|c|c|c|}
\hline & Banking crisis & Currency crisis & Debt crisis \\
\hline Gabon & & 1994 & 1986; 2002 \\
\hline Gambia, The & & $1985 ; 2003$ & 1986 \\
\hline Georgia & 1991 & $1992 ; 1999$ & \\
\hline Ghana & 1982 & 1978; 1983; 1993; 2000; 2009; 2014 & \\
\hline Grenada & & & 2004 \\
\hline Guatemala & & 1986 & \\
\hline Guinea & $1985 ; 1993$ & $1982 ; 2005$ & 1985 \\
\hline Guinea-Bissau & $1995 ; 2014$ & 1980; 1994 & \\
\hline Guyana & 1993 & 1987 & 1982 \\
\hline Haiti & 1994 & $1992 ; 2003$ & \\
\hline Honduras & & 1990 & 1981 \\
\hline Hungary & $1991 ; 2008$ & & \\
\hline India & 1993 & & \\
\hline Indonesia & 1997 & $1979 ; 1998$ & 1999 \\
\hline Iran, Islamic Rep. & & $1985 ; 1993 ; 2000 ; 2013$ & 1992 \\
\hline Jamaica & 1996 & $1978 ; 1983 ; 1991$ & 1978; 2010 \\
\hline Jordan & 1989 & 1989 & 1989 \\
\hline Kazakhstan & 2008 & 1999; 2015 & \\
\hline Kenya & $1985 ; 1992$ & 1993 & \\
\hline Kuwait & 1982 & & \\
\hline Kyrgyz Republic & 1995 & 1997 & \\
\hline Lao PDR & & 1972; 1978; 1986; 1997 & \\
\hline Lebanon & 1990 & $1984 ; 1990$ & \\
\hline Lesotho & & $1985 ; 2015$ & \\
\hline Liberia & 1991 & & 1980 \\
\hline Libya & & 2002 & \\
\hline Madagascar & 1988 & 1984; 1994; 2004 & 1981 \\
\hline Malawi & & 1994; 2012 & 1982 \\
\hline Malaysia & 1997 & 1998 & \\
\hline Maldives & & 1975 & \\
\hline Mali & 1987 & 1994 & \\
\hline Mauritania & 1984 & 1993 & \\
\hline Mexico & 1981; 1994 & 1977; 1982; 1995 & 1982 \\
\hline Moldova & 2014 & 1999 & 2002 \\
\hline Mongolia & 2008 & $1990 ; 1997$ & \\
\hline Morocco & 1980 & 1981 & 1983 \\
\hline Mozambique & 1987 & 1987; 2015 & 1984 \\
\hline Myanmar & & $1975 ; 1990 ; 1996 ; 2001 ; 2007 ; 2012$ & \\
\hline Namibia & & $1984 ; 2015$ & \\
\hline Nepal & 1988 & 1984; 1992 & \\
\hline New Caledonia & & 1981 & \\
\hline Nicaragua & $1990 ; 2000$ & $1979 ; 1985 ; 1990$ & 1980 \\
\hline
\end{tabular}


Appendix 3. List of financial crises (continued)

\begin{tabular}{|c|c|c|c|}
\hline & Banking crisis & Currency crisis & Debt crisis \\
\hline Niger & 1983 & 1994 & 1983 \\
\hline Nigeria & $1991 ; 2009$ & 1983; 1989; 1997; 2016 & 1983 \\
\hline Norht Macedonia & 1993 & & \\
\hline Pakistan & & 1972 & \\
\hline Panama & 1988 & & 1983 \\
\hline Papua New Guinea & & 1995 & \\
\hline Paraguay & 1995 & 1984; 1989; 2002 & 1982 \\
\hline Peru & 1983 & $1976 ; 1981 ; 1988$ & 1978 \\
\hline Philippines & $1983 ; 1997$ & $1983 ; 1998$ & 1983 \\
\hline Poland & 1992 & & 1981 \\
\hline Romania & 1998 & 1996 & 1982 \\
\hline Russian Federation & $1998 ; 2008$ & 1998; 2014 & 1998 \\
\hline Rwanda & & 1991 & \\
\hline Sao Tome \& Principe & 1992 & 1987; 1992; 1997 & \\
\hline Senegal & 1988 & 1994 & 1981 \\
\hline Serbia & & 2000 & \\
\hline Seychelles & & 2008 & 2008 \\
\hline Sierra Leone & 1990 & $1983 ; 1989 ; 1998$ & 1977 \\
\hline South Africa & & $1984 ; 2015$ & 1985 \\
\hline South Sudan & & 2015 & \\
\hline Sri Lanka & 1989 & 1978 & \\
\hline Sudan & & 1981; 1988; 1993; 2012 & 1979 \\
\hline Suriname & & 1990; 1995; 2001; 2016 & \\
\hline Syrian Arab Republic & & 1988 & \\
\hline Tajikistan & & $1999 ; 2015$ & \\
\hline Tanzania & 1987 & $1985 ; 1990$ & 1984 \\
\hline Thailand & $1983 ; 1997$ & 1998 & \\
\hline Togo & 1993 & 1994 & 1979 \\
\hline Trinidad \& Tobago & & 1986 & 1989 \\
\hline Tunisia & 1991 & & \\
\hline Turkey & $1982 ; 2000$ & 1978; 1984; 1991; 1996; 2001; 2018 & 1978 \\
\hline Turkmenistan & & 2008 & \\
\hline Uganda & 1994 & $1980 ; 1988$ & 1981 \\
\hline Ukraine & 1998; 2008; 2014 & 1998; 2009; 2014 & $1998 ; 2015$ \\
\hline Uruguay & $1981 ; 2002$ & $1972 ; 1983 ; 1990 ; 2002$ & $1983 ; 2002$ \\
\hline Uzbekistan & & 2000; 2017 & \\
\hline Venezuela, RB & 1994 & $1984 ; 1989 ; 1994 ; 2002 ; 2010$ & $1982 ; 2017$ \\
\hline Vietnam & 1997 & $1972 ; 1981 ; 1987$ & 1985 \\
\hline Yemen, Rep. & 1996 & $1985 ; 1995$ & \\
\hline \multicolumn{2}{|c|}{ Yugoslavia, The former SFR } & & 1983 \\
\hline Zambia & 1995 & $1983 ; 1989 ; 1996 ; 2009 ; 2015$ & 1983 \\
\hline Zimbabwe & 1995 & $1983 ; 1991 ; 1998 ; 2003$ & \\
\hline
\end{tabular}

Note: Years of crises are taken from Laeven and Valencia (2018), while the list includes currency crises in 2017 and 2018, which are computed with data on nominal exchange rates from the IMF and the methodology described in Laeven and Valencia (2018). 
Appendix 4. Definition of variables and data sources

\begin{tabular}{|c|c|c|}
\hline Variable & Definition & Source \\
\hline Crisis & Sovereign debt, banking, or currency crisis & Laeven and Valencia (2018) \\
\hline $\begin{array}{l}\text { Change in U.S. real interest } \\
\text { rate }\end{array}$ & $\begin{array}{l}\text { Percentage point change in U.S. real lending interest rate (deflated by GDP } \\
\text { deflator) }\end{array}$ & WDI \\
\hline GDP growth & $\begin{array}{l}\text { Annual percentage growth rate of GDP at market prices based on constant } \\
\text { local currency }\end{array}$ & WDI \\
\hline Short-term debt & Share of short-term debt (with a maturity of 1 year or less) in external debt & IDS \\
\hline Debt service & Ratio of debt service on external debt to exports & IDS \\
\hline Reserve cover & International reserves in months of imports & IDS \\
\hline Change in government debt & Percentage point change in public debt to GDP ratio & GDD \\
\hline Change in private debt & Percentage point change in private debt to GDP ratio & GDD \\
\hline Concessional debt & Share of concessional debt in external debt & IDS \\
\hline Funding ratio & Ratio of credit provided to private sector to total deposits & GFDD \\
\hline Currency overvaluation & Percentage deviation of real effective exchange rate from HP-filtered trend & Darvas (2018), World Bank \\
\hline Currency mismatch & Ratio of foreign liabilities to foreign assets & Lane and Milesi-Ferretti (2018) \\
\hline FDI & Net inflows of foreign direct investment as a share of GNI & IDS \\
\hline
\end{tabular}

Note: GFDD - Global Financial Development Database; GDD - Global Debt Database, IDS - International Debt Statistics; WDI - World Development Indicators. 


\section{Appendix 5. Selected case studies of debt accumulation}

Four country cases illustrate the difference between countries that suffered financial crises and those that did not during the 1970s-2000s. Countries that suffered crises had more accommodative policies and greater vulnerabilities to external shocks.

To sharpen the role of different structural and institutional features in driving macroeconomic outcomes during rapid debt accumulation episodes, this section focuses on a select set of country case studies in the 1970s-1990s. Two country pairs are singled out with rapid debt accumulation episodes at about the same time, of which one country had a financial crisis while the other did not during their national episodes of rapid debt accumulation.

In the 1970s and 1980s, both Mexico and Indonesia had rapid government debt accumulation episodes but only Mexico suffered a triple crisis in 1982. In the 1990s, both Thailand and Chile witnessed rapid private debt buildups but only Thailand suffered a crisis in 1997.

Two differences feature in both country pairs: first, those with financial crises maintained considerably more accommodative fiscal and monetary policy than those without crises; second, those with financial crises had greater existing vulnerabilities (e.g., higher short-term debt or higher total debt).

\section{Mexico in the 1970s and 1980s}

Debt accumulation. Mexico borrowed heavily in foreign currency (mostly U.S. dollars) against future oil revenues in the 1970s. Central government debt rose by almost 20 percentage points of GDP between 1972 and 1982, to 32 percent of GDP in 1982 (Figure A.5.1). External debt grew from 19 percent of GDP in 1972 to 30 percent of GDP in 1981. Inflation averaged 24 percent a year during 1979-81, despite a peg to the U.S. dollar, and the current account deficit widened to 5.1 percent of GDP. Mexico pursued an import substitution industrialization policy in the 1970s, which generated economic inefficiencies that would have necessitated fundamental change at some point. It also pursued expansionary fiscal and monetary policies, with widening fiscal and current account deficits. While a balance of payment crisis briefly struck in 1976, oil discoveries and the oil price shock in the late 1970s delayed necessary structural reforms and allowed another fiscal expansion.

Adverse shocks. In October 1979, the U.S. Federal Reserve began to tighten monetary policy and short-term interest rates rose sharply. This coincided with a global economic slowdown and a sharp decline in commodity prices, particularly oil prices. As a result of the twin shocks, compounded by three-quarters of interest payments being tied to variable interest rates, Mexico's debt service payments surged in 1982. In addition, the overvalued exchange rate generated fears of devaluation and a balance of payments crisis, triggering capital flight. The peso was allowed to float freely in early 1982 and depreciated sharply. Mexico's external debt reached 47 percent of GDP (of which one-third was short-term), debt service costs increased to 53 percent of exports, and reserves plunged to less than 1 percent of total debt.

Financial crisis. In August 1982, Mexico defaulted on its sovereign debt. Although Mexico's debt was not the largest, it sparked a series of defaults and systematic collapse in Latin America (Boughton 2001). GDP growth plunged from an average of 9.0 percent in 1980-81 to

-0.1 percent during 1982-87. The peso collapsed; between 1981 and 1982 it depreciated by more than half, and by 1987 it had lost 98 percent of its value. Inflation soared and averaged 84 percent a year during 1982-87. The debt crisis also led to a banking crisis and the government nationalized the entire banking system. 


\section{Indonesia in the 1970s and 1980s}

Debt accumulation. During 1972-80, the period during which Mexico's central government debt rose rapidly, Indonesia's central government debt initially declined by almost 20 percentage points of GDP as oil revenues improved fiscal positions. Starting in 1980, however, central government debt climbed rapidly from 14 percent of GDP in 1980 to 46 percent of GDP in 1987. The global recession of the early 1980s widened the current account deficit to 6 percent of GDP in 1983. The authorities responded with fiscal consolidation.

Macroeconomic policies. As with Mexico, U.S. monetary policy tightening, and global economic weakness triggered intermittent currency pressures in 1983 and 1986. The rupiah was allowed to depreciate amid tightly enforced capital controls, high reserves (15 percent of total debt) and a small share of short-term debt (15 percent of external debt; Arndt and Hill 1988). Monetary policy was tightened with modest short-term interest rate increases and direction to state-owned enterprises to move funds from state banks into central bank notes. Inflation declined and capital flight was limited. The government also implemented various reforms from 1983, including deregulation of the banking system, the introduction of a value-added tax, trade liberalization, and privatization of the large state enterprise sector. During 1980-87 growth averaged 5.6 percent.

\section{Thailand in the 1990s}

Debt accumulation. Private debt grew rapidly to a peak of 146 percent of GDP in 1997 from 51 percent of GDP a decade earlier, while central government debt declined by more than 30 percentage points of GDP to 5 percent of GDP in 1997. Following rapid financial sector liberalization in the early 1990s, sizeable interest rate differentials, combined with an exchange rate peg, encouraged large capital inflows. Real estate investment grew rapidly, largely funded with short-term external debt. This exposed corporations and banks to significant exchange rate and rollover risks. Poorly governed privatizations to politically connected entities and governmentdirected credit towards political allies created moral hazard in the form of expectations of government guarantees to politically connected lending. Although bank deposits were not explicitly insured by the government, political considerations and past practice suggested that the Thai government would bail out failing banks (Burnside, Eichenbaum, and Rebelo 2004).

Financial Crisis. By 1996, unsold properties began to accumulate, and investors concerned about defaults started withdrawing capital, putting downward pressure on the baht. The government initially raised interest rates, introduced capital controls, and drew down foreign exchange reserves but eventually allowed the baht to float in July 1997. By the end of 1997, the currency had depreciated by about 40 percent and the stock market had lost two-fifths of its value. Bankruptcies soared, growth plunged from 5.7 percent in 1996 to -2.8 percent in 1997 and -7.6 percent in 1998, and many banks became insolvent. Following widespread nationalizations and bank closures, Thailand's government debt reached 30 percent of GDP in 2002, from 4 percent in 1996 . The crisis spread across much of East Asia.

\section{Chile in the 1990s}

Debt accumulation. Private debt rose rapidly from 59 percent of GDP in 1987 to 91 percent of GDP in 1997-only one-third as much as the private debt increase in Thailand over the same period - and further to 116 percent of GDP in 2002. The buildup in private debt was more than offset by a marked decline in government debt, from 82 percent of GDP to 15 percent of GDP over 1987-2002. During 1987-1997 in the runup to the Asian financial crisis, Chile's decline in central government debt was twice as steep as that in Thailand.

Macroeconomic policies. During the 1990s, disciplined fiscal, monetary and financial policy stances were maintained. Since the mid-1980s, fiscal balances had been in surplus, and in 2000 an explicit 
structural budget surplus rule was introduced. This fiscal rule helped to institutionalize fiscal discipline and to lock in the credibility that had been built up in the past decades. Exchange rate policy had shifted from a semi-fixed regime to a floating regime with an inflation-targeting framework in 1999. Monetary credibility had also been enhanced through an independent central bank, decreed in 1989. Inflation had fallen from close to 30 percent in the early 1990s to less than 3 percent in 2002 .

After the collapse of Chilean banks during the Latin American debt crisis in the 1980s, the government made sweeping changes to the banking law and adopted a better regulatory framework to reduce exposure to external shocks (Cowan and de Gregorio 2007). As a result, Chilean banks had an average capital adequacy ratio of 13 percent and non-performing loans were below 2 percent during 1988-2002.

\section{Similarities and differences}

These cases illustrate two main differences between those countries where rapid debt accumulation coincided with crises and those where it did not. First, countries without crises had relatively more modest debt buildups. Whereas government debt rose rapidly in Mexico, it declined in Chile in the runup to the sharp rise in global interest rates in the early 1980s. Government debt in Indonesia and in Chile had declined for a decade before global interest rates began rising sharply in the early 1980s (Indonesia) or risk sentiment turned against EMDEs in the late 1990s (Chile). As a result, both governments were better placed than their counterparts in Mexico and Thailand, respectively, to withstand external shocks. Private debt rose two-thirds less in Chile than in Thailand in the runup to the Asian financial crisis, adding to Chile's greater financial resilience.

Second, countries without crises had less accommodative policies. While Indonesia's fiscal policy tightened during its government debt runup in the mid-1980s, Mexico's fiscal policy remained expansionary during its government debt runup in the 1970s despite double digit inflation and weakening current account balances. In part due to a fiscal rule and flexible exchange rates, Chile maintained fiscal surpluses and discouraged currency mismatches during the 1980s and 1990s whereas Thailand's accommodative monetary policy after financial liberalization and pegged exchange rate regimes fueled a property boom and encouraged currency mismatches. 
Figure A.5.1. Debt in selected countries

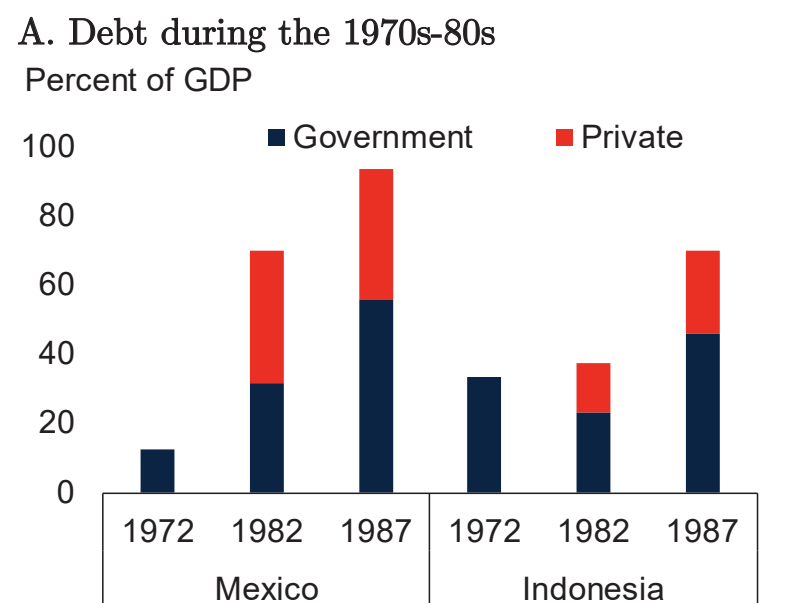
A. Debt during the $1980 \mathrm{~s}-2000 \mathrm{~s}$ Percent of GDP

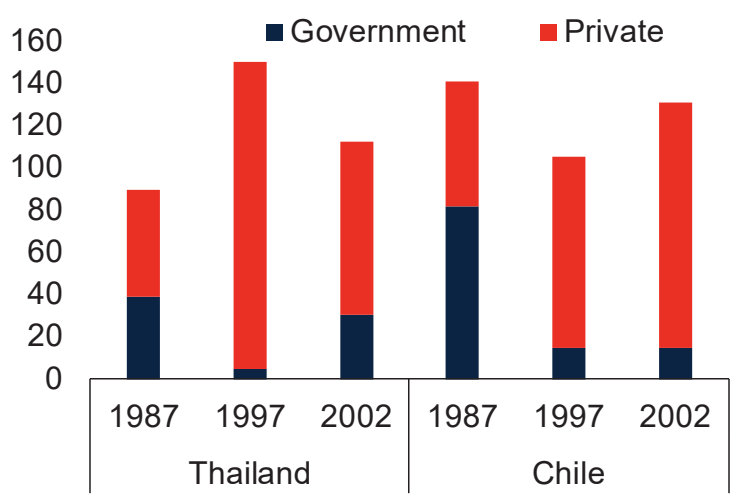

Source: Mbaye, Moreno Badia and Chae (2018).

Note: Figures show the evolution of government and private debt in different episodes. Government and private debt are proxied by central government debt and credit to the private sector, respectively. Private debt data not available for 1972 for Mexico and Indonesia. 
Appendix 6. Country-case study sources

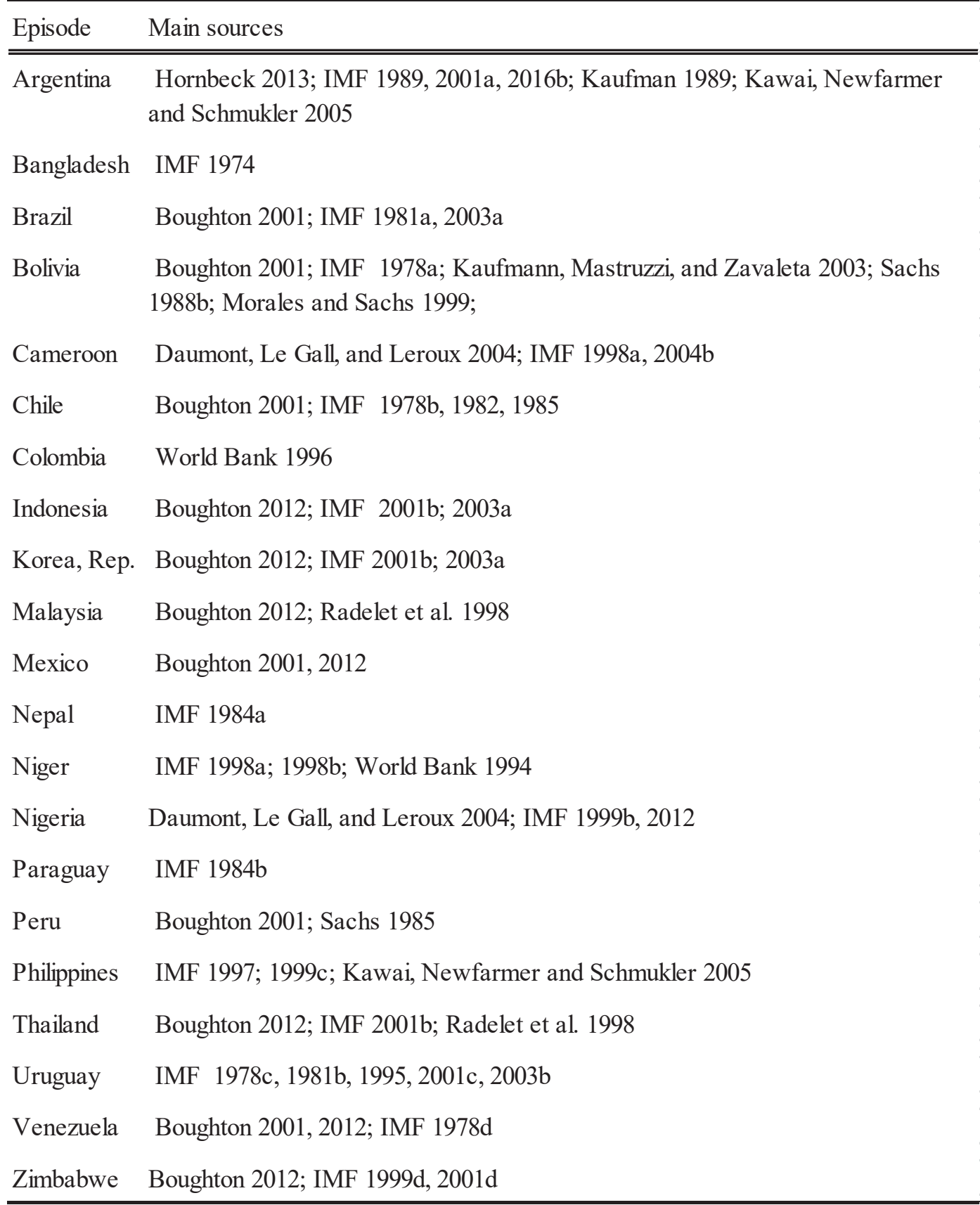

Note: Unless otherwise specified, IMF references refer to Article IV staff reports. 


\section{References}

Abbas, A., A. Pienkowski, and K. Rogoff. 2019. Sovereign Debt: A Guide for Economists and Practitioners. New York: Oxford University Press.

Acharya, V., Drechsler, I., and Schnabl, P. 2014. "A Pyrrhic Victory? Bank Bailouts and Sovereign Credit Risk." Journal of Finance 69 (6): 2689-2739.

Arndt, H., and Hill, H. 1988. "The Indonesian Economy: Structural Adjustment After the Oil Boom." Southeast Asian Affairs: 106-119.

Balassa, B. 1982. Development Strategies in Semi-Industrial Economies. Washington, DC: World Bank.

Baldacci, E., I. Petrova, N. Belhocine, G. Dobrescu, and S. Mazraani. 2011. "Assessing Fiscal Stress." IMF Working Paper 11/100, International Monetary Fund, Washington, DC.

Blanchard, O. 2019. "Public Debt and Low Interest Rates." American Economic Review 109 (4): 1197-1229.

Berg, A., E. Borensztein, and C. Pattillo. 2005. "Assessing Early Warning Systems: How Have They Worked in Practice?" IMF Staff Papers 52 (3): 462-502.

Borio, C., and P. Lowe. 2002. "Assessing the Risk of Banking Crises." BIS Quarterly Review 7 (1): 43-54.

Borensztein, E., and Panizza, U. 2009. "The Costs of Sovereign Default." IMF Staff Papers 56 (4): 683-741.

Borio, C., and Lowe, P. 2002. "Asset Prices, Financial and Monetary Stability: Exploring the Nexus." BIS Working Papers 114, Bank for International Settlements, Basel.

Boughton, J. 2001. Silent Revolution: The International Monetary Fund 1979-1989. Washington, DC: International Monetary Fund.

Brownbridge, M., and C. Kirkpatrick. 2000. "Financial Regulation in Developing Countries." The Journal of Development Studies 31 (1): 1-24.

Bulow, J., and Rogoff, K. 1989. "Sovereign Debt: Is it to Forgive or Forget?" American Economic Review 79 (1): 43-50.

Burnside, C., Eichenbaum, M., and Rebelo, S. 2000. "Understanding the Korean and Thai Currency Crises." Economic Perspectives Quarter III: 45-60, Federal Reserve Bank of Chicago.

- 2004. "Government Guarantees and Self-fulfilling Speculative Attacks." Journal of Economic Theory 119 (1): 31-63.

Calvo, G. 1988. "Servicing the Public Debt: The Role of Expectations." American Economic Review 78 (4): 647-661.

Capulong, M.V., D. Edwards, D. Webb, and J. Zhuang. 2000. An Analytic Framework of Corporate Governance and Finance. Corporate Governance and Finance in East Asia: A Study of Indonesia, Republic of Korea, Malaysia, Philippines, and Thailand. Manila: Asian Development Bank. 
Chamon M., and C. Crowe. 2012. "Predictive Indicators of Crises." In Handbook in Financial Globalization: The Evidence and Impact of Financial Globalization, edited by G. Caprio, 499505. London: Elsevier.

Chang, R., and Velasco, A. 1999. "Liquidity Crises in Emerging Markets: Theory and Policy." NBER Macroeconomics Annual 14 (1): 11-58.

—. 2000. "Financial Fragility and the Exchange Rate Regime." Journal of Economic Theory $92(1): 1-34$.

Citron, J-T., and Nickelsburg, J. 1987. "Country Risk and Political Instability." Journal of Development Economics 25 (2): 385-392.

Claessens, S., and M. A. Kose. 2018. "Frontiers of Macrofinancial Linkages." BIS Papers 95, Bank for International Settlements, Basel.

Claessens, S., M. A. Kose, and M. Terrones. 2012. "How do Business and Financial Cycles Interact?" Journal of International Economics 87 (1): 178-90.

Cole, H. L., and Kehoe, T. J. 2000. "Self-fulfilling Debt Crises." The Review of Economic Studies 67 (1): 91-116.

Cuadra, G., and Sapriza, H. 2008. "Sovereign Default, Interest Rates and Political Uncertainty in Emerging Markets." Journal of International Economics 76 (1): 78-88.

Daumont, R., F. Le Gall, and F. Leroux. 2004. "Banking in Sub-Saharan Africa: What Went Wrong?" IMF Working Paper 04/55, International Monetary Fund, Washington, DC.

Dawood, M., N. Horsewood, and F. Strobel. 2017. "Predicting Sovereign Debt Crises: An Early Warning System Approach." Journal of Financial Stability, 28: 16-28.

Dell'Ariccia, G, D. Igan, L. Laeven, and H. Tong. 2014. "Policies for Macrofinancial Stability: Dealing with Credit Booms and Busts." In Financial Crises: Causes, Consequences, and Policy Responses, edited by S. Claessens, M. A. Kose, L. Laeven, and F. Valencia. Washington, DC: International Monetary Fund.

—. 2016. "Credit Booms and Macrofinancial Stability." Economic Policy 31 (86): 299-355.

Demirgüç-Kunt, A., and E. Detragiache. 1998. "The Determinants of Banking Crises in Developing and Developed Countries." Staff Papers 45 (1): 81-109.

Diamond, D., and Dybvig, P. 1983. "Bank Runs, Deposit Insurance, and Liquidity." Journal of Political Economy 91 (3): 401-419.

Dornbusch, R., I. Goldfajn, R. Valdés, S. Edwards, and M. Bruno. 1995. "Currency Crises and Collapses." Brookings Papers on Economic Activity 1995 (2): 219-293.

Eaton, J., and Gersovitz, M. 1981. "Debt with Potential Repudiation: Theoretical and Empirical Analysis." The Review of Economic Studies 48 (2): 289-309.

Eichengreen, B., Hausmann, R., and Panizza, U. 2002. "Original Sin: The Pain, the Mystery and the Road to Redemption", paper prepared for the conference on Currency and Maturity Matchmaking: Redeeming Debt from Original Sin, Inter-American Development Bank, Washington, DC. 
Eichengreen, B., A. K. Rose, and C. Wyplosz. 1995. "Exchange Market Mayhem: The Antecedents and Aftermath of Speculative Attacks." Economic Policy 10 (21): 249-312.

Elekdag, S., and Y. Wu. 2013. "Rapid Credit Growth in Emerging Markets: Boon or BoomBust?" Emerging Markets Finance and Trade 49 (5): 45-62.

Enoch, C., and I. Ötker-Robe. 2007. "Lessons from Country Experiences with Rapid Credit Growth, and Policy Implications." In Rapid Credit Growth in Central and Eastern Europe, 349366. London: Palgrave Macmillan.

Flood, R., and Garber, P. 1984. "Collapsing Exchange-rate Regimes: Some Linear Examples." Journal of International Economics 17 (1-2): 1-13.

Flood, R., and Marion, N. 2000. "Self-fulfilling Risk Predictions: An Application to Speculative Attacks." Journal of International Economics 50 (1): 245-268.

Forbes, K. J. 2004. "Capital Controls: Mud in the Wheels of Market Discipline." NBER Working Paper 10284, National Bureau of Economic Research, Cambridge, MA.

- 2007. "The Microeconomic Evidence on Capital Controls: No Free Lunch." In Capital Controls and Capital Flows in Emerging Economies: Policies, Practices and Consequences, edited by S. Edwards, 171-202. Chicago: University of Chicago Press.

Forbes, K., M. Fratzscher, and R. Straub. 2015. "Capital-Flow Management Measures: What Are They Good For?" Journal of International Economics 96 (July): S76-S97.

Frankel, J. A., and A. K. Rose. 1996. "Currency Crashes in Emerging Markets: An Empirical Treatment." Journal of International Economics 41 (3-4): 351-366.

Frankel, J. A., and G. Saravelos. 2012. "Can Leading Indicators Assess Country Vulnerability? Evidence from the 2008-09 Global Financial Crisis." Journal of International Economics 87 (2): 216-231.

Furceri, D., and Zdzienicka, A. 2012. "How Costly are Debt Crises?" Journal of International Money and Finance 31 (4): 726-742.

Gennaioli, N., Martin, A., and Rossi, S. 2014. "Sovereign Default, Domestic Banks, and Financial Institutions." Journal of Finance 69 (2): 819-866.

Gourinchas, P.-O., R. Valdes, and O. Landerretche. 2001. "Lending Booms: Latin America and the World." NBER Working Paper 8249, National Bureau of Economic Research, Cambridge, MA.

Harding, D., and A. Pagan. 2002. "Dissecting the Cycle: A Methodological Investigation." Journal of Monetary Economics 49 (2): 365-381.

IMF (International Monetary Fund). 1974. Bangladesh-Staff Report and Proposed Decision for the 1974 Article XIV Consultation. Washington, DC: International Monetary Fund.

. 1978a. Bolivia: Staff Report for the 1978 Article IV Consultation. Washington, DC: International Monetary Fund.

. 1978b. Chile: Staff Report for the 1978 Article IV Consultation. Washington, DC: International Monetary Fund.

- 1978c. Uruguay: Staff Report for the 1978 Article IV Consultation. Washington, DC: 
International Monetary Fund.

1978d. Venezuela: Staff Report for the 1978 Article IV Consultation. Washington, DC: International Monetary Fund.

. 1981a. Brazil: Staff Report for the 1981 Article IV Consultation. Washington, DC: International Monetary Fund.

—. 1981b. Uruguay: Staff Report for the 1981 Article IV Consultation. Washington, DC: International Monetary Fund.

- 1982. Chile: Staff Report for the 1982 Article IV Consultation. Washington, DC: International Monetary Fund.

- 1984a. Nepal: Staff Report for the 1984 Article IV Consultation. Washington, DC: International Monetary Fund.

- 1984b. Paraguay: Staff Report for the 1984 Article IV Consultation. Washington, DC: International Monetary Fund.

- 1985. Chile: Staff Report for the 1985 Article IV Consultation. Washington, DC: International Monetary Fund.

-1989. Argentina-Staff Report for the 1989 Article IV Consultation and Request for Stand-By Arrangement. Washington, DC: International Monetary Fund.

- 1995. Uruguay: Staff Report for the 1995 Article IV Consultation. Washington, DC: International Monetary Fund.

-1997. Philippines: Staff Report for the 1997 Article IV Consultation. Washington, DC: International Monetary Fund.

—. 1998a. "External Debt Histories of Ten Low-Income Developing Countries: Lessons From their Experience." IMF Working Paper 72, International Monetary Fund, Washington, DC.

- 1998b. Niger: Staff Report for the 1998 Article IV Consultation. Washington, DC: International Monetary Fund.

-1999a. Report of the Managing Director to the Interim Committee on Progress in Strengthening the Architecture of the International Financial System. Washington, DC: International Monetary Fund.

- 1999b. Nigeria: Staff Report for the 1999 Article IV Consultation. Washington, DC: International Monetary Fund.

- 1999c. Philippines - Staff Report for the 1999 Article IV Consultation, Fourth Review Under the Stand-By Arrangement, and Request for Waiver and Modification of Performance Criteria. Washington, DC: International Monetary Fund.

-1999d. Zimbabwe: Staff Report for the 1999 Article IV Consultation. Washington, DC: International Monetary Fund.

- 2000a. Recovery from the Asian Crisis and the Role of the IMF. Washington, DC: International Monetary Fund.

2000b. Financial Sector Assessment Program (FSAP) A Review: Lessons from the Pilot 
and Issues Going Forward. Washington, DC: International Monetary Fund.

2001a. Argentina: 2001 Article IV Consultation Staff Report. Washington, DC: International Monetary Fund.

- 2001b. IMF-Supported Programs in Indonesia, Korea, Thailand: A Preliminary Assessment. Washington, DC: International Monetary Fund.

. 2001c. Uruguay: Staff Report for the 2001 Article IV Consultation. Washington, DC: International Monetary Fund.

. 2001d. Zimbabwe: Staff Report for the 2001 Article IV Consultation. Washington, DC: International Monetary Fund.

2002. A New Approach to Sovereign Debt Restructuring. Washington, DC: International Monetary Fund.

- 2003a. The IMF and Recent Capital Account Crises: Indonesia, Korea, Brazil. Washington, DC: International Monetary Fund.

- 2003b. Uruguay: Staff Report for the 2003 Article IV Consultation. Washington, DC: International Monetary Fund.

- 2004a. The IMF and Argentina, 1991-2001. Washington, DC: International Monetary Fund.

C. 2004b. Cameroon: 2004 Article IV Consultation Staff Report. Washington, DC: International Monetary Fund.

- 2012. The Liberalization and Management of Capital Flows-An Institutional View. Washington, DC: International Monetary Fund.

- 2015. The IMF's Institutional View on Capital Flows in Practice. Washington, DC: International Monetary Fund.

Jeanne, O. 2003. "Why do Emerging Economics Borrow in Foreign Currency?" IMF Working Paper 03/177, International Monetary Fund, Washington, DC.

Jordà, Ò., M. Schularick, and A. M. Taylor. 2011. "Financial Crises, Credit Booms, and External Imbalances: 140 Years of Lessons." IMF Economic Review 59 (2): 340-378.

Kaminsky, G. L., S. Lizondo, and C. M. Reinhart. 1998. "Leading Indicators of Currency Crises." IMF Staff Papers 45 (1): 1-48.

Kaminsky, G. L., and C. M. Reinhart. 1999. "The Twin Crises: The Causes of Banking and Balance-of-Payments Problems." American Economic Review 89 (3): 473-500.

—. 2000. "On Crises, Contagion, and Confusion." Journal of International Economics 51 (1): $145-168$.

Kaufmann, D., A. Kraay, and M. Mastruzzi. 2010. "The Worldwide Governance Indicators: Methodology and Analytical Issues." Policy Research Working Paper 5430, World Bank, Washington, DC.

Kaufman, R. R. 1989. "The Politics of Economic Adjustment Policy in Argentina, Brazil, and Mexico: Experiences in the 1980s and Challenges for the Future." Policy Sciences 22 (3): 395-413. 
Kauko, K. 2014. "How to Foresee Banking Crises? A Survey of the Empirical Literature." Economic Systems 38 (3): 289-308.

Kawai, M., R. Newfarmer, and S. Schmukler. 2005. "Crisis and Contagion in East Asia: Nine Lessons." Eastern Economic Journal 31 (2): 185-207.

Kindleberger, C. P., and R. Z. Aliber. 2011. Manias, Panics and Crashes: A History of Financial Crises. London: Palgrave Macmillan.

Kose, M. A., P. Nagle, F. Ohnsorge and N. Sugawara. 2019. "Global Waves of Debt." World Bank, Washington, DC.

Kose, M. A., F. Ohnsorge and N. Sugawara. Forthcoming. "The Dose Makes the Poison." Policy Research Working Paper, World Bank, Washington. DC.

Krugman, P. 1979. "A Model of Balance-of-Payments Crises." Journal of Money, Credit and Banking 11 (3): 311-325.

. 1999. "Balance Sheets, the Transfer Problem, and Financial Crises." International Tax and Public Finance 6 (4): 459-472.

_. 2019. "Perspectives on Debt and Deficits." Business Economics 54 (3): 157-159.

Laeven, L., and F. Valencia. 2010. Policy Responses to Systemic Banking Crises." In Macrofinancial Linkages: Trends, Crises, and Policies, edited by Crowe, C., S Johnson, J. Ostry, and J. Zettelmeyer. Washington, DC: International Monetary Fund.

. 2018. "Systemic Banking Crises Revisited." IMF Working Paper 18/206, International Monetary Fund, Washington, DC.

Lahiri, A., and Végh, C. 2003. "Delaying the Inevitable: Interest Rate Defense and Balance of Payments Crises." Journal of Political Economy 111 (2): 404-424.

Manasse, P., Roubini, N., and Schimmelpfenning, A. 2003. "Predicting Sovereign Debt Crises." IMF Working Paper 03/221, International Monetary Fund, Washington, DC.

Mbaye, S., M. Moreno-Badia, and K. Chae. 2018. "Global Debt Database: Methodology and Sources." IMF Working Paper 18/111, International Monetary Fund, Washington, DC.

Mendoza, E. G., and M. E. Terrones. 2008. "An Anatomy of Credit Booms: Evidence from Macro Aggregates and Micro Data." NBER Working Paper 14049, National Bureau of Economic Research, Cambridge, MA.

. 2012. "An Anatomy of Credit Booms and their Demise" NBER Working Paper 18379, National Bureau of Economic Research, Cambridge, MA.

Moreno Badia, M., P. Medas, P. Gupta, and Y. Xiang. 2020. "Debt is not Free." IMF Working paper 20/1, International Monetary Fund, Washington, DC.

Obstfeld, M., and Rogoff, K. 1986. "Ruling Out Divergent Speculative Bubbles." Journal of Monetary Economics 17 (3): 349-362.

OECD. 2003. OECD Economic Surveys: Chile 2003. Paris: Organisation for Economic Cooperation and Development.

Ohnsorge, F., and S. Yu. 2016. "Recent Credit Surge in Historical Context." Policy Research Working Paper 7704, World Bank, Washington, DC. 
Reinhart, C. 2002. "Default, Currency Crises, and Sovereign Credit Ratings." World Bank Economic Review 16 (2): 151-170.

Reinhart, C., V. Reinhart, and K. Rogoff. 2012. "Public Debt Overhangs: Advanced-Economy Episodes Since 1800." Journal of Economic Perspectives 26 (3): 69-86.

Reinhart, C. M., and K. S. Rogoff. 2009. This Time Is Different. Eight Centuries of Financial Folly. Princeton, NJ: Princeton University Press.

1706 .

Rogoff, K. 2019. "Government Debt is Not A Free Lunch." Project Syndicate, December 6. https://www.project-syndicate.org/commentary/government-debt-lowinterest-rates-no-freelunch-by-kenneth-rogoff-2019-11.

Romer, C. D., and D. H. Romer. 2017. "New Evidence on the Aftermath of Financial Crises in Advanced Countries." American Economic Review 107 (10): 3072-3118.

Rose, A. K., and M. M. Spiegel. 2012. "Dollar Illiquidity and Central Bank Swap Arrangements During the Global Financial Crisis." Journal of International Economics 88 (2): 326-340.

Roubini, N., and P. Wachtel. 1999. "Current-Account Sustainability in Transition Economies." In Balance of Payments, Exchange Rates, and Competitiveness in Transition Economies, edited by M. I. Blejer and M. Škreb. Boston: Kluwer Academic Publishers.

Sachs, J. 1985. "External Debt and Macroeconomic Performance in Latin America and East Asia." Brookings Papers on Economic Activity 1985 (2): 523-573.

- 1989. "New Approaches to the Latin American Debt Crisis." In Essays in International Finance 174 Princeton, NJ: Princeton University Press.

Schularick, M., and A. M. Taylor. 2012. "Credit Booms Gone Bust: Monetary Policy, Leverage Cycles, and Financial Crises, 1870-2008." American Economic Review 102 (2): 1029-1061.

Tornell, A., and F. Westermann. 2005. Boom-Bust Cycles and Financial Liberalization. Cambridge, MA: MIT Press Books.

Uvalic, M. 2011. "Insights From a Transition Economy: The Case of Serbia." IEG Distinguished Lecture 4, The Institute of Economic Growth, New Delhi, India.

World Bank. 2016. Global Economic Prospects: Divergences and Risks. June. Washington, DC: World Bank.

- 2019a. Global Economic Prospects: Heightened Tensions, Subdued Investment. June. Washington, DC: World Bank. 